\title{
Chitosan-Based (Nano)Materials for Novel Biomedical Applications
}

\author{
Gregor Kravanja ${ }^{1}$, Mateja Primožič ${ }^{1}$, Željko Knez ${ }^{1,2}$ and Maja Leitgeb ${ }^{1,2, *}$ \\ 1 Laboratory for Separation Processes and Product Design, Faculty of Chemistry and Chemical Engineering, \\ University of Maribor, Smetanova ul. 17, 2000 Maribor, Slovenia; gregor.kravanja@um.si (G.K.); \\ mateja.primozic@um.si (M.P.); zeljko.knez@um.si (Ž.K.) \\ 2 Faculty of Medicine, University of Maribor, Taborska ulica 8, 2000 Maribor, Slovenia \\ * Correspondence: maja.leitgeb@um.si; Tel.: +386-2-2294-462
}

Academic Editor: Jyh-Ping Chen

Received: 26 April 2019; Accepted: 18 May 2019; Published: 21 May 2019

\begin{abstract}
Chitosan-based nanomaterials have attracted significant attention in the biomedical field because of their unique biodegradable, biocompatible, non-toxic, and antimicrobial nature. Multiple perspectives of the proposed antibacterial effect and mode of action of chitosan-based nanomaterials are reviewed. Chitosan is presented as an ideal biomaterial for antimicrobial wound dressings that can either be fabricated alone in its native form or upgraded and incorporated with antibiotics, metallic antimicrobial particles, natural compounds and extracts in order to increase the antimicrobial effect. Since chitosan and its derivatives can enhance drug permeability across the blood-brain barrier, they can be also used as effective brain drug delivery carriers. Some of the recent chitosan formulations for brain uptake of various drugs are presented. The use of chitosan and its derivatives in other biomedical applications is also briefly discussed.
\end{abstract}

Keywords: chitosan; antimicrobial; nanomaterials; mode of action; brain drug delivery carrier; biomedicine

\section{Introduction}

Chitosan is a naturally-occurring, linear polysaccharide produced from chitin by deacetylation in the solid state under alkaline conditions, or by enzymatic hydrolysis of chitin deacetylase. It is considered to be the second largest renewable biomaterial after cellulose in terms of utilization and distribution [1]. In recent years, chitosan and its derivative biomaterials have attracted significant attention in the biomedical field, owing to their unique biological properties. Some of the most noted properties of chitosan in the medical context are its non-toxicity, biodegradability, biocompatibility, and immunoenhancing, antitumoral, antibacterial and antimicrobial activity (Figure 1). The biodegradability of chitosan was proven both in vitro and in vivo, where macromolecules were split into several smaller sections of monomers [2]. Chitosan and its enzymatic degradation products could safely interact with living cells without any adverse effect in the body. Chitosan could decrease cholesterol absorption [3], interrupt the chain oxidation process by sifting free radicals [4], and act as an antimicrobial and antibacterial against many bacteria, yeasts and fungi [5]. It is suggested that the antimicrobial activity of chitosan and its derivative biomaterials relies on numerous factors like the degree of deacetylation, molar weight, $\mathrm{pH}$, the presence of metal cations, $\mathrm{pKa}$ and microorganism species [6]. Chitosan-based nanoparticles can also inhibit tumor cell growth by inducing apoptosis, with a high permeability and retention effect. Particles up to about 100-200 nm in size can be adopted by receptor-mediated endocytosis, while larger particles have to be taken by phagocytosis [7]. Chitosan, either alone or mixed with other polymers, active agents and metallic nanocomposites, has been extensively used in many biomedical applications, including in wound dressing as an antimicrobial 
agent [8], in drug delivery as a nano-sized carrier to target tumor tissue while minimally affecting sites of normal tissue, [9], for gene delivery [10], hemodialysis [11] and dentistry [12] as well as for absorbable structures for immobilized enzymes [13].

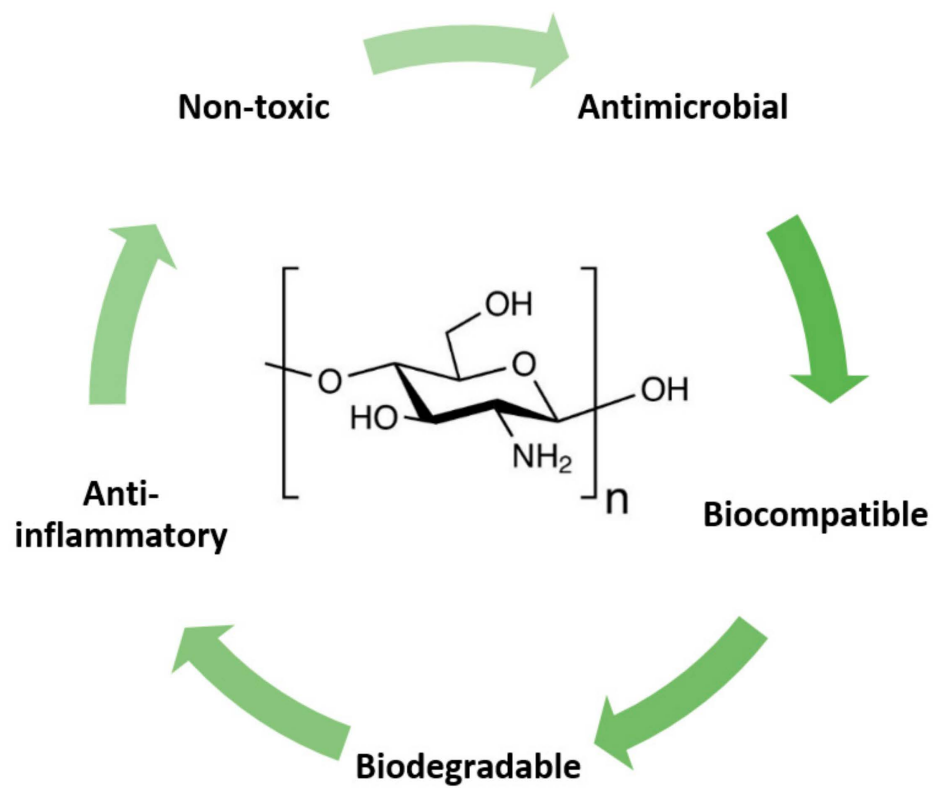

Figure 1. Unique biological properties allow the use of chitosan in many biomedical applications.

In this article, we present several emerging biomedical applications including chitosan-based biomaterials, where two of most commonly investigated by the scientific community are highlighted: antimicrobial wound dressing and drug delivery including formulations for brain uptake. Firstly, insights about the antibacterial effects and mode of action of chitosan-based nanomaterials and their role as carriers for drug delivery are presented. Chitosan is proposed as an excellent antimicrobial wound dressing nanomaterial, either in its native form or formulated with antimicrobial substances to additionally increase its antimicrobial effect. Since chitosan and its derivatives can enhance drug permeability across the blood-brain barrier, they can also be used as excellent brain drug delivery carriers. Some of the recent chitosan formulations for brain uptake of various drugs are presented. The use of chitosan and its derivatives in other biomedical applications is also briefly discussed.

\section{Antimicrobial Nature of Chitosan}

\subsection{Mode of Action}

Although the exact antimicrobial mechanism of chitosan and its derivatives is not yet fully understood, several hypotheses about the mode of action have recently been proposed and accepted (Table 1 and Figure 2). The most generally accepted hypothesis is that positively-charged amine groups $\left(\mathrm{NH}^{3+}\right)$ of glucosamine interact with the negatively charged surface of bacteria, causing leakage of intracellular constituents that results in cell death [14]. Other possibilities include the binding of chitosan with DNA that inhibits mRNA after it penetrates to the nuclei of microorganisms. A study of Echerichia coli using a confocal laser microscope suggests that chitooligomers were present within the cell and probably prevent DNA transcription [6]. Another option is a chelating effect by chitosan that binds essential metals and thereby inhibits microbial growth. It is well known that chitosan has excellent metal-binding abilities, where amino charged groups interact with metals [15]. The interaction between amino groups and divalent ions like $\mathrm{Ca}^{2+}$ and $\mathrm{Mg}^{2+}$ present in the microorganism cell wall prevents the production of toxins and inhibits bacterial growth. The fourth hypothesis presents chitosan as a blocking agent that blocks nutrients and oxygen from entering the cell. 
Table 1. Recent studies of various hypotheses on the mechanism of chitosan antimicrobial action.

\begin{tabular}{|c|c|}
\hline Antimicrobial Mechanism & Findings \\
\hline Polycationic nature of chitosan & $\begin{array}{l}\text { - The interaction between positively-charged chitosan molecules and negatively } \\
\text { charged microbial cell membranes leads to leakage of intracellular constituents } \\
\text { [16,17] } \\
\text { - The binding neutralizes and reverses the surface charge of bacteria } \\
\text { - Cationic groups increase E. coli membrane permeability and membrane lysis [18] }\end{array}$ \\
\hline $\begin{array}{l}\text { Binding to bacterial DNA } \\
\text { (inhibition of mRNA) }\end{array}$ & $\begin{array}{l}\text { - Binding to bacterial DNA leads to inhibition of mRNA and consequently } \\
\text { protein synthesis } \\
\text { The low molecular weight }(\leq 50 \mathrm{kDa}) \text { chitosan and nano-sized particles can } \\
\text { penetrate the bacteria cell wall and inhibit DNA transcription [14] } \\
\text { Binding of chitosan to bacterial DNA was commonly investigated for gene } \\
\text { delivery [19] } \\
\text { - The mechanism of DNA binding ability and its antimicrobial activity are not yet } \\
\text { fully understood }\end{array}$ \\
\hline
\end{tabular}

- Chitosan selectively binds essential metals and thereby inhibits microbial growth and the production of toxins [20]

Chelation agent (nutrients and essential metals)

- Higher inhibitory efficiency at high $\mathrm{pH}$ where positive ions are bonded to chitosan

- Activates defense processes in host tissue [17]

- Acts as a water-binding agent that inhibits several enzymes [21]
Blocking agent

- Chitosan can form a layer on the surface of the bacteria cell and prevent nutrients from entering the cell [22]

- Blocking the oxygen path and inhibiting the growth of aerobic-type bacteria [23]
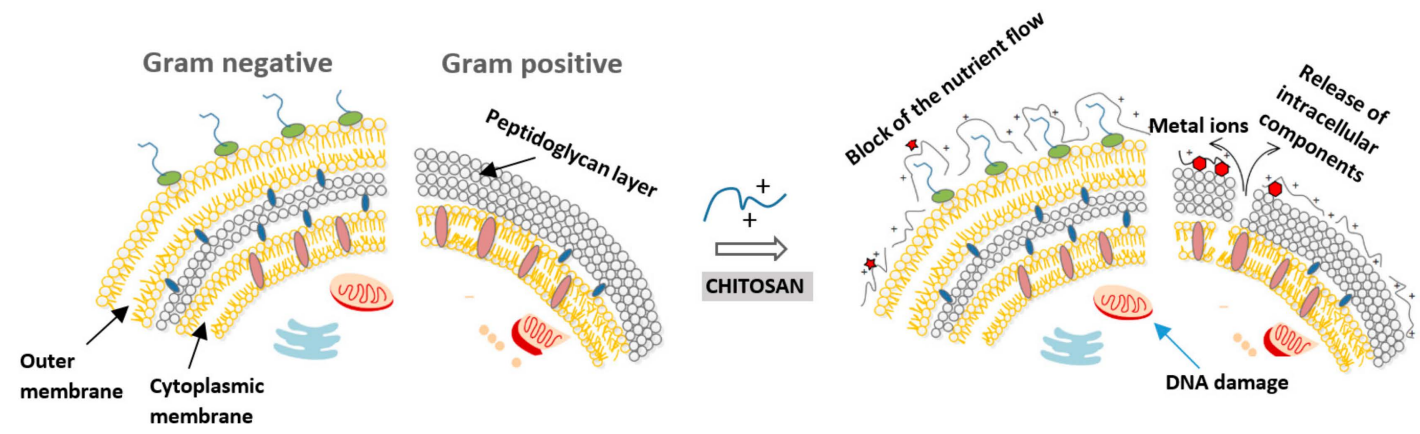

Figure 2. Four proposed models for the action of chitosan on Gram-positive and -negative bacteria: The polycationic nature of chitosan causes the release of intercellular components, binding to bacterial DNA (inhibition of mRNA), blocking the nutrient flow and chelation of essential metals.

\subsection{Effect of Factors on the Antimicrobial Activity of Chitosan}

Several factors are recognized to affect the antimicrobial activity of chitosan and can be divided into three main categories: environmental factors, fundamental factors of chitosan and factors affecting different types of microorganism.

\subsubsection{Environmental Factors}

Environmental $\mathrm{pH}$ is one of the most important factors affecting the antimicrobial activity of chitosan and its derivatives. Chitosan shows its antimicrobial effect only in an acidic medium, since it possesses poor solubility at high $\mathrm{pH}(\mathrm{pH} \geq 6.5)$. The reason for that may lie in the fact that the majority of amino groups become uncharged near $\mathrm{pH} 7$ [24]. To overcome this limitation, chitosan has been systematically modified to yield derivatives with improved aqueous solubility. It has three types of reactive functional groups that can be further modified with quaternary ammoniumyl, guaindinyl, 
carboxyalkyl, long alkyl chains and thiol groups [25]. Another environmental factor includes the effect of the temperature during storage of chitosan. To date, the effect of temperature has been evaluated only for chitosan but not its derivatives. One study reveals that a chitosan solution stored for 15 weeks at $4{ }^{\circ} \mathrm{C}$ showed the highest antimicrobial effect against Listeria monocotgenes, Salmonella enterica, Staphylococcus aureus and E. coli, compared to one stored at $25^{\circ} \mathrm{C}$ [26].

\subsubsection{Fundamental Factors}

In the case of lower molecular weight, the size and conformation of chitosan appear to be fundamental, since mobility, attraction and ionic interaction are easier with small chains than with larger ones, resulting in effective binding to the membrane surface [5]. However, the relation between antibacterial activity and molecular weight also depends on the type of microorganism. One study showed that the growth of gram-positive and gram-negative bacteria was inhibited only by a molecular weight lower than $470 \mathrm{kDa}$, while toward E. coli, the opposite effect was found [27]. In the same way, but differing in intensity, the chitosan antimicrobial effect was improved as the degree of acetylation decreased [5]. In the process of deacetylation, acetyl groups from chitin are removed to form amino groups and determine the degree of deacetylation (the content of free amino groups in chitosan) [28]. In a study by Takahashi et al. [27] using mannitol salt agar and conductometric assay, the influence of the degree of deacetylation was investigated against the inhibition of S. aureus. A lower degree of deacetylation more successfully inhibited the growth of bacteria. In contrast, Byun et al. reported that the activity of chitosan, prepared from the ground shell with a degree of deacetylation of $81.6 \%$ is greater than that of chitosan prepared from the entire shell with a degree of deacetylation of $62 \%$ [29]. The reason for that could be that chitosan with a higher degree of deacetylation has more positively-charged free amino groups influencing the antimicrobial characteristics.

\subsubsection{Type of Microorganism}

It was found that chitosan exhibits diverse inhibitory efficiency against different bacteria and fungi. The mode of antibacterial activity is a very complex process that varies between Gram-positive and Gram-negative bacteria, based on differences in cell structure (Figure 2). Gram-negative bacteria have an outer membrane that contains lipopolysaccharides that provide bacteria with hydrophilic surface properties. The outer membrane serves as a barrier against macromolecules and hydrophobic toxins. In the case of Gram-positive bacteria, the surface is made of peptidoglycans and teichoic acid, crucial for many membrane-bound enzymes to function. Many studies, with some exceptions, suggest that a higher inhibitory effect can be found in Gram-negative bacteria [30]. Younes et al. showed that the bactericidal effect was further enhanced for Gram-negative bacteria when chitosan molar weight decreased [31]. As with the bacterial effect, chitosan activity is assumed to be fungistatic rather than fungicidal [5]. There is no need for chemical modification of chitosan to activate its antifungal activity. The reason for the antifungal activity of chitosan is its polycationic nature. The formation of chelates with trace elements makes them unavailable for normal growth of fungi. Next, negatively charged membrane phospholipids interact with positively-charged chitosan, which increases the permeability of the membrane. The result is leakage of cellular content and subsequently, cell death. Chitosan may also penetrate the cell wall of fungi and bind to its DNA. However, chitosan nanoparticles increase its antifungal effect significantly [32]. Chitosan nanoparticles prepared from various concentrations of low molecular weight and high molecular weight were also found to provide better inhibitory activity against Candida albicans and Fusarium solani compared to chitosan in the solution form [33]. In the search for new agents with antifungal activity against Candida, chitosan obtained from Pleurotus spp. showed promising results. With regard to chitosan biofilms, important for biomedical applications, it was found that reduced biomass and metabolic activity in both the adhesion phase and in the mature biofilms display no significant difference for the strains of Candida parapsilosis sensu stricto and Candida tropicalis [33], using different molecular weights of chitosan [30]. 
Influence of environmental, fundamental factors of chitosan and factors affecting different types of microorganism are presented in Table 2.

Table 2. Influence of three main factors affecting the antimicrobial activity of chitosan.

\begin{tabular}{|c|c|}
\hline $\begin{array}{l}\text { Factors Influencing } \\
\text { Antimicrobial Activity }\end{array}$ & Findings \\
\hline \multicolumn{2}{|l|}{ Environmental Factors } \\
\hline $\mathrm{pH}$ & $\begin{array}{l}\text { - Higher antimicrobial activity at low } \mathrm{pH} \text { (ionized amino groups) [34] } \\
\text { At } \mathrm{pH} \leq 6 \text {, positively-charged amino groups interconnected with } \\
\text { proteins, fatty acids, phospholipids and consequently with negative } \\
\text { charged bacterial membrane [35] }\end{array}$ \\
\hline Temperature & $\begin{array}{l}\text { Different temperatures influence chitosan antimicrobial activity during } \\
\text { storage [36] } \\
\text { - } \quad \text { Temperature affects chitosan viscosity and molecular weight [36] }\end{array}$ \\
\hline \multicolumn{2}{|l|}{ Fundamental Factors } \\
\hline Molecular weight & $\begin{array}{l}\text { - High molecular weight chitosan could stack on the bacterial surface } \\
\text { and block nutrient transport, resulting in cell death [37] } \\
\text { Lower molecular weight }(\leq 50 \mathrm{kDa}) \text { chitosan could penetrate the } \\
\text { membrane surface and bind with DNA, thus inhibiting synthesis of } \\
\text { mRNA [38] }\end{array}$ \\
\hline Degree of acetylation & $\begin{array}{l}\text { - A higher positively-charged chitosan is associated with the degree of } \\
\text { acetylation [39] } \\
\text { A } 30-40 \% \text { degree of acetylation produced the highest antibacterial } \\
\text { activity against S. aureus and E. coli [40] }\end{array}$ \\
\hline \multicolumn{2}{|l|}{ Type of Microorganism } \\
\hline Gram-positive bacteria & $\begin{array}{l}\text { - Comprises peptidoglycan and teichoic acid responsible for structural } \\
\text { constancy of cell wall [41] }\end{array}$ \\
\hline Gram-negative bacteria & $\begin{array}{l}\text { - It is suggested that chitosan possesses the strongest bactericidal effect } \\
\text { on Gram-negative bacteria [41] } \\
\text { - Gram-negative bacteria have a cell wall of a thick peptidoglycan layer } \\
\text { that has a highly negative charge [40] }\end{array}$ \\
\hline Fungi & $\begin{array}{l}\text { - Antifungal activity decreased with increasing molar weight and } \\
\text { decreasing degree of acetylation [31] } \\
\text { - Chitosan in solution or chitosan films displayed varying efficiency on } \\
\text { fungal growth [42] }\end{array}$ \\
\hline
\end{tabular}

In many studies, the assay conditions for determination of chitosan minimal inhibitory concentration (MIC) have not been standardized; it is therefore difficult to make effective comparisons between studies. Table 3 presents a set of several uniform and standard measurements, taking into account the effect of acetylation degree, molecular weight, and $\mathrm{pH}$ on MIC. 
Table 3. Minimal inhibitory concentration (MIC) of chitosan against three types of microorganisms.

\begin{tabular}{|c|c|c|c|c|c|}
\hline Type of Microorganism & $\mathrm{pH}$ & $\begin{array}{c}\text { Mw } \\
(k D a)\end{array}$ & $\begin{array}{c}\text { Degree of } \\
\text { Acetylation (\%) }\end{array}$ & $\begin{array}{c}\text { MIC } \\
(\mu \mathrm{g} / \mathrm{mL})\end{array}$ & Ref. \\
\hline \multicolumn{6}{|l|}{ Gram-positive } \\
\hline Bacillus cereus & 5.5 & 43 & 6 & 60 & [22] \\
\hline Bacillus cereus & 6 & $2.3-224$ & $16-48$ & $80-2000$ & [43] \\
\hline Bacillus megaterium & 5.9 & $28-1670$ & - & $500-800$ & [26] \\
\hline Lactobacillus brevis & 5.9 & 224-1106 & - & 500-1000 & [26] \\
\hline Lactobacillus bulgaricus & 5.9 & $28-1670$ & - & up to 1000 & [26] \\
\hline Listeria monocytogenes & 6 & 49-1100 & $2-53$ & 150 & [44] \\
\hline Staphylococcus aureus & 5.9 & 28-1106 & - & $800-10000$ & [26] \\
\hline \multicolumn{6}{|l|}{ Gram-negative } \\
\hline Escherichia coli & 6 & $49-1100$ & - & $100-500$ & [44] \\
\hline Escherichia coli & 5.9 & $28-1670$ & $2-53$ & 800-1000 & [26] \\
\hline Escherichia coli & 6 & $3-224$ & $16-48$ & $30-2000$ & [43] \\
\hline Enterobacter aerogenes & 5.5 & 43 & 6 & 60 & [22] \\
\hline Pseudomonas aeruginosa & 6 & $49-1100$ & $2-53$ & $150-200$ & [44] \\
\hline Pseudomonas fluorescens & 5.5 & 43 & 6 & 80 & [22] \\
\hline Salmonella typhimurium & 6 & $49-1670$ & $2-53$ & $1500-2000$ & [44] \\
\hline Vibrio cholera & 6 & $49-1100$ & $2-53$ & 200 & [44] \\
\hline \multicolumn{6}{|l|}{ Fungi } \\
\hline Botrytis cinerea & - & - & - & 10 & [6] \\
\hline Candida lambica & 5.5 & 43 & 6 & 400 & [22] \\
\hline Drechstera sorokiana & - & - & - & 10 & [6] \\
\hline Fusarium oxysporum & 6 & 49-1100 & $2-57$ & $500-2000$ & {$[44]$} \\
\hline Microsporum canis & - & - & - & 1000 & [6] \\
\hline Micronectriella nivalis & - & - & - & 10 & [6] \\
\hline Trichophyton equinum & - & - & - & 2500 & [6] \\
\hline
\end{tabular}

\section{Chitosan in Biomedical Applications}

Chitosan-based nanomaterials have attracted significant attention in a wide variety of biomedical fields because of their unique chemical properties, including desired biodegradability, compatibility and non-toxicity. In tissue engineering, chitosan is a suitable biomaterial to construct extracellular tissue matrixes [45]. It can be used as a carrier for brain drug delivery and for various ocular therapeutic molecules such as drugs, genes and proteins in ophthalmology that deal with visual system diseases. Another medical application involves its use in renal failure and hemodialysis [46]. Chitosan is widely used as a carrier in delivering active agents and drugs [47], in gene and cancer therapy [48], in biosensor monitoring and bio imaging [49,50]. In dentistry, chitosan acts as an anti-plaque agent and can interfere with all microorganisms, while exhibiting antibacterial activity [51]. As an antimicrobial and antifungal agent, chitosan is most commonly used in wound dressing, since it possesses excellent tissue-adhesive properties [52].

\subsection{Wound Dressing}

The healing process of a wound comprises a cascade synchronized events: hemostasis, inflammation, migration, proliferation and remodeling [53]. To ensure an effective wound healing process, many labs around the word started to develop antimicrobial wound dressings [54]. Among the many synthetic or natural materials in use, chitosan is an excellent choice on account of its distinctive properties, since it possesses intrinsic antimicrobial properties and offers the capacity to deliver extrinsic antimicrobial agents to the infected area. Chitosan can be easily fabricated into the desired asymmetric, porous skin scaffolds [55], hydrogels [56], sponges [57], membranes [58] and films without toxic chemicals [59]. Hydrogels are characterized by their high capacity to store water within their structure and can be used to moisten the infected area [60]. The swelling properties of hydrogels in saline solution need to be characterized in detail for potential biomedical applications. Their drawbacks include poor mechanical properties and the need for additional upgrading with secondary dressing [61]. Sponges are nothing 
more than foams with high open porosity and swelling properties, providing excellent matrixes to most wounded areas. However, these may incite skin maceration and are inappropriate for treatment of third-degree wounds [62]. Films used in biomedical applications must be resistant to bacteria and allow therapeutic monetization [63]. Nevertheless, this type of dressing could adhere to the wound bed and exudate accumulation [64]. Membranes are a commonly used type of wound dressing, as they can provide three-dimensional matrices with high surface-volume ratio to guarantee a good nutrient supply and cell proliferation. Chitosan-based antimicrobial wound dressing can be fabricated either alone, by using only native molecules, or upgraded and incorporated with antibiotics (ciprofloxacin, gentamicin, sulfadiazine or tetracycline), metallic antimicrobial particles ( $\mathrm{nAg}, \mathrm{nCu}, \mathrm{nZnO}$ and $\mathrm{nTiO}_{2}$ ) and natural compounds and extracts (Juglena regia, Salix alba leaves, honey, Aloe vera etc.) ${ }^{\circledR}$ [54-59].

In the native form, many commercial wound dressings are available on the market, including HidroKi $^{\circledR}$, Chitpack $^{\circledR}$, Patch $^{\circledR}$, Tegasorb $^{\circledR}$ and KytoCel ${ }^{\circledR}$ [54]. In order to increase the antimicrobial effect, chitosan is often functionalized with antibiotics. Antibiotics incorporated into chitosan matrices can interfere with the function of the bacterial structure or with metabolic pathways. They ca also interfere with cell wall biosynthesis [65], block key metabolic pathways as they mimic folic acid structure [66], or interfere with protein synthesis and can inhibit replication or transcription processes [67]. Recently, metallic antimicrobial particles, incorporated into chitosan scaffolds/bandages, have received much interest in clinical scenarios ranging from $\mathrm{nAg}$ based wound dressing, to nAg coated medical devices [68]. The main problems associated with metallic nanoparticles are their genotoxic, oxidative and cytotoxic effects [69]. However, the toxic effect can be significantly reduced by using chitosan-based biomaterials as carriers or surface coatings [70]. Among the metallic nanoparticles, $\mathrm{nAg}$ have attracted the most attention, owing to their broad inhibitory activity against many antibiotic-resistant bacteria [71]. Anishia et al. [72] presented antimicrobial sponges composed by chitosan, hyaluronic acid and nAg as wound dressing to treat diabetic foot ulcers infected with drug-resistant bacteria. Antibacterial activity of the prepared sponges was analyzed using E. coli, S. aureus, methicillin-resistant S. aureus (MRSA), P. aeruginosa and Klebsiella pneumoniae. Sponges containing higher $\mathrm{nAg}(0.005 \%, 0.01 \%$ and $0.02 \%)$ concentrations showed antibacterial activity against drug-resistant bacteria. In a recent survey, metallic composites were united with natural products to increase their antibacterial nature and biocompatibility [73]. An increasing number of chitosan-based wound dressings have been formulated with natural compounds and extracts in order to increase antimicrobial activity [74,75]. A. vera is a natural compound that has been extensively studied in combination with chitosan for antimicrobial dressing applications [76]. Silva et al. [77] highlighted the use of chitosan and $A$. vera membranes as active wound dressing materials useful for skin repair. Nguyen et al. [78] prepared composite sponges that were made with 10\% curcumin and from chitosan and gelatin with various ratios. An in vivo study indicated better wound closure in wounds treated with curcumin-composite sponge than those with composite sponge without curcumin and an untreated group. Honey is one of the natural products that displays high bactericidal activity [79]. A range of honey-impregnated wound dressings is already on the market, including MediHoney [80], Actilite [81] and Algivon [82]. Honey from the Manuka tree is the most promising type of honey, since it contains a non-peroxide component and can sustain bacterial growth inhibition over time [83]. To date, there has been no publication about chitosan-based wound dressings containing Manuka tree honey. Table 4 presents several of the proposed and used wound dressings, prepared either as native chitosan or modified and formulated with other antimicrobial substances to additionally increase its antimicrobial effect. 
Table 4. Recent chitosan-based wound dressings prepared either as native chitosan or modified and formulated with other antimicrobial substances.

\begin{tabular}{|c|c|c|c|c|}
\hline & Type & Findings & Tested Microorganisms & Ref. \\
\hline \multicolumn{5}{|c|}{ Native Chitosan-Based Biomaterials } \\
\hline Chitosan/PVA/starch & Membrane & $\begin{array}{l}\text { Excellent cell growth and } \\
\text { proliferation }\end{array}$ & $\begin{array}{c}\text { Escherichia coli, } \\
\text { Staphylococcus aureus }\end{array}$ & {$[84]$} \\
\hline $\begin{array}{c}\text { Chitosan } / \beta \text {-cyclodextrin } \\
\text { polymer }\end{array}$ & Sponge & $\begin{array}{c}\text { Controlled swelling and drug } \\
\text { delivery }\end{array}$ & $\begin{array}{l}\text { Staphylococcus aureus, } \\
\text { Escherichia coli }\end{array}$ & {$[85]$} \\
\hline Chitosan & Hydrogel & $\begin{array}{l}\text { Superb antifungal and } \\
\text { antimicrobial effects }\end{array}$ & $\begin{array}{l}\text { Pseudomonas aeruginosa, } \\
\text { Escherichia coli, } \\
\text { Fusarium solani }\end{array}$ & [86] \\
\hline Chitosan & Membrane & $\begin{array}{l}\text { Epithelialization rate was } \\
\text { increased }\end{array}$ & $\begin{array}{l}\text { Pseudomonas aeruginosa, } \\
\text { Staphylococcus aureus }\end{array}$ & {$[58]$} \\
\hline Chitosan/PVP/nano-cellulose & Film & $\begin{array}{l}\text { In vitro wound dressing } \\
\text { application was significant }\end{array}$ & Staphylococcus aureus & {$[87]$} \\
\hline $\begin{array}{l}\text { Chitosan-distamycin and } \\
\text { vancomycin }\end{array}$ & Films & $\begin{array}{l}80 \% \text { degrees of deacetylation were } \\
\text { optimal for eluting antibiotics }\end{array}$ & Staphylococcus aureus & {$[88]$} \\
\hline \multicolumn{5}{|c|}{ Chitosan and Antibiotics } \\
\hline $\begin{array}{c}\text { Chitosan nanofiber } \\
\text { mesh-gentamicin-loaded } \\
\text { liposomes }\end{array}$ & Membrane & Antibacterial activity & $\begin{array}{l}\text { Escherichia coli, Pseudomonas } \\
\text { aeruginosa, Staphylococcus aureus }\end{array}$ & [89] \\
\hline $\begin{array}{l}\text { Chitosan/poly(2-hydroxyethyl } \\
\text { acrylate)-levofloxacin }\end{array}$ & Sponge & $\begin{array}{c}\text { The prepared dressing shows a } \\
\text { significant inhibition zone of } \\
\text { bacteria strains }\end{array}$ & $\begin{array}{l}\text { Methicillin- susceptible } \\
\text { Staphylococcus aureus, } \\
\text { Methicillin-resistant } \\
\text { Staphylococcus aureus }\end{array}$ & {$[90]$} \\
\hline Chitosan-vancomycin & Aerogel & Low-density, large surface area & $\begin{array}{c}\text { Staphylococcus aureus } \\
\text { Escherichia coli, Staphylococcus }\end{array}$ & [91] \\
\hline Chitosan/sulfadiazine & Sponge & Antibacterial activity & $\begin{array}{c}\text { aureus, } \\
\text { Bacillus subtilis }\end{array}$ & [92] \\
\hline \multicolumn{5}{|c|}{ Chitosan-Entrapped Metallic Nanoparticles } \\
\hline $\begin{array}{l}\text { Chitosan/sodium } \\
\text { alginate- } \mathrm{Cu}\end{array}$ & Hydrogel & $\begin{array}{l}\text { Safe to use in contact with living } \\
\text { cells }\end{array}$ & $\begin{array}{l}\text { Methicillin-resistant } \\
\text { Staphylococcus aureus, } \\
\text { Escherichia coli }\end{array}$ & [93] \\
\hline Quaternized chitosan-nAg & Film & Property with antibacterial effects & $\begin{array}{c}\text { Escherichia coli, Staphylococcus } \\
\text { aureus, Pseudomonas aeruginosa, } \\
\text { Candida albicans }\end{array}$ & [94] \\
\hline Chitosan-nAu & Film & $\begin{array}{l}\text { nAu interacts with cell wall and } \\
\text { inhibits mitochondrial membrane }\end{array}$ & $\begin{array}{c}\text { Staphylococcus aureus, } \\
\text { Pseudomonas aeruginosa }\end{array}$ & [95] \\
\hline Chitosan/algetic acid-nZnO & Sponge & $\begin{array}{c}\text { Potential to be an antibacterial } \\
\text { topical hemostat }\end{array}$ & Staphylococcus aureus & [96] \\
\hline Chitosan/gelatin- $\mathrm{nFe}_{3} \mathrm{O}_{4}$ & & $\begin{array}{c}\mathrm{Fe}_{3} \mathrm{O}_{4} \text { enhanced mechanical and } \\
\text { antibacterial properties }\end{array}$ & $\begin{array}{c}\text { Escherichia coli, } \\
\text { Staphylococcus aureus }\end{array}$ & [97] \\
\hline Chitosan/ECM-nTiO 2 & Composite & $\begin{array}{c}\text { Faster regeneration of granulation } \\
\text { tissue }\end{array}$ & $\begin{array}{c}\text { Escherichia coli, Staphylococcus } \\
\text { aureus }\end{array}$ & [98] \\
\hline \multicolumn{5}{|c|}{ Chitosan Entrapped with Plant Extracts } \\
\hline $\begin{array}{l}\text { Chitosan- amorphophallus } \\
\text { konjac plant }\end{array}$ & Film & $\begin{array}{l}\text { Low cytotoxicity and inhibition of } \\
\text { microbial penetration. }\end{array}$ & $\begin{array}{c}\text { Escherichia coli, Staphylococcus } \\
\text { aureus, } \\
\text { Pseudomonas aeruginosa }\end{array}$ & [99] \\
\hline $\begin{array}{l}\text { Chitosan- Hypericum } \\
\text { perforatum }\end{array}$ & Film & $\begin{array}{l}\text { The highest strain value was } \\
\text { obtained in } 0.25 \% \text { oil content films }\end{array}$ & $\begin{array}{c}\text { Escherichia coli, } \\
\text { Staphylococcus aureus }\end{array}$ & [100] \\
\hline Chitosan- Aloe vera & Membrane & $\begin{array}{l}\text { Promising wound dressing } \\
\text { material }\end{array}$ & $\begin{array}{c}\text { Escherichia coli, } \\
\text { Staphylococcus aureus } \\
\text { Escherichia coli, }\end{array}$ & [101] \\
\hline Chitosan-thyme oil & Films & $\begin{array}{l}\text { Antibacterial activity on all } \\
\text { studied microorganisms }\end{array}$ & $\begin{array}{l}\text { Staphylococcus aureus, } \\
\text { Klebsiella pneumoniae }\end{array}$ & [102] \\
\hline $\begin{array}{c}\text { Poly(vinyl } \\
\text { alcohol)/chitosan-honey }\end{array}$ & Hydrogel & $\begin{array}{l}\text { Faster honey release rate at higher } \\
\text { pH values }\end{array}$ & Staphylococcus aureus & [103] \\
\hline Chitosan/gelatin-curcumin & Sponge & $\begin{array}{l}\text { Enhances the formation of } \\
\text { collagen and wound closure } \\
\text { in vivo }\end{array}$ & Pseudomonas aeruginosa & {$[78]$} \\
\hline
\end{tabular}

\subsection{Tissue Engineering for Bone Regeneration}

Three-dimensional porous scaffolds for bone tissue engineering must be biocompatible and allow osteogenesis. A variety of techniques have been developed to mimic the microstructure and properties of natural mineralized materials. Still, facile and rapid fabrication of large-size bulk materials with high calcium content under ambient conditions remains a major challenge. During gelation, a controllable inorganic gradient distribution forms, along with mineralization, where urea was used, 
and spontaneously hierarchically ordered hydrogel microstructures were formed. This fabrication route takes only hours to complete the gelation and mineralization processes [104].

Composite scaffolds have been fabricated using a coaxial electrospinning technique to prepare gelatin-chitosan core-shell structured nanofibers. An arginine-glycine-aspartic acid (RGD)-like structure was formed to mimic the organic component of the extracellular matrix of natural bone. Later, by a wet chemical method, hydroxyapatite was deposited on the surface of the prepared-shell structured nanofibers. Hydroxyapatite is the major mineral constituent of natural bone. Gelatin-chitosan core-shell structured nanofibers improved the mineralization efficiency of hydroxyapatite compared to chitosan nanofibers [105]. The design of biologically-active scaffolds is focused on the application of cell-adhesive proteins or bioceramic nanoparticles to produce a cell-sensitive surface. Therefore, trace metals found in the living organisms were used to prepare biocompatible chitosan hydrogels. These were modified by copper (II) ions through complexation interactions and yielded a less stable cytocompatible to more stable cytotoxic structure for a copper-chitosan system [106,107].

From the perspective of antibacterial effects, Zhou et al. [108] synthesized a biodegradable rhBMP-2-loaded zein-based scaffold with SBA-15 and hydroxypropyltrimethyl ammonium chloride chitosan (HACC) nanoparticles incorporated into the scaffolds. Results showed that the sample zein-HACC-S20 exhibited long-lasting antibacterial activity against E. coli and S. aureus. In another

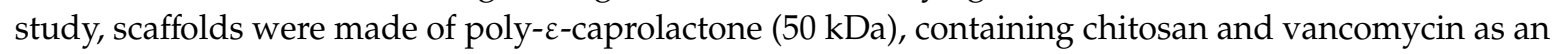
antimicrobial agent for bone regeneration purposes. The scaffolds sustained vancomycin release for more than 2 weeks. The scaffolds were tested against Gram-positive (S. aureus) and Gram-negative (E. coli) bacteria after $24 \mathrm{~h}$ of incubation with full growth inhibition for S. aureus [109]. Although in this subsection only limited insight is provided on using chitosan for bone tissue engineering, there is immense future clinical potential in fabricating composite materials using chitosan as an antimicrobial and mechanical support biomaterial for better cell proliferation.

\subsection{Chitosan as a Brain Drug Delivery Carrier}

Peptide and protein drug delivery systems could be improved by chitosan and its derivatives [110]. The molecular dynamics simulation results revealed that the native conformation of insulin was stabilized by the chitosan polymers [111]. Chitosan has also been extensively studied in brain drug delivery [112]. The reason is that it can enhance drug permeability across the blood-brain barrier by affecting the tight junction. Chitosan nanoparticles can be absorbed on the negatively charged cell membrane, owing to the positive charge on the surface and can increase the residence time on the nasal mucosa. The delivery of drugs from the nasal cavity to the brain can thus be improved. Chitosan nanoparticles may be surface modified with tumor-targeting peptides like chlorotoxin and transferrin, which can further improve the capacity for targeting a brain tumor [113]. The demand for more effective therapeutics has led to the development of multiple strategies to reach the brain tissue (Figure 3). Some of these rely on the transient disruption of the blood-brain barrier by using osmotic pressure, ultrasound or pharmacological entities, while others are based on intra-cerebro-ventricular (ICV) infusion, convection-enhanced delivery, intra-cerebral injection or the use of implants [114]. 


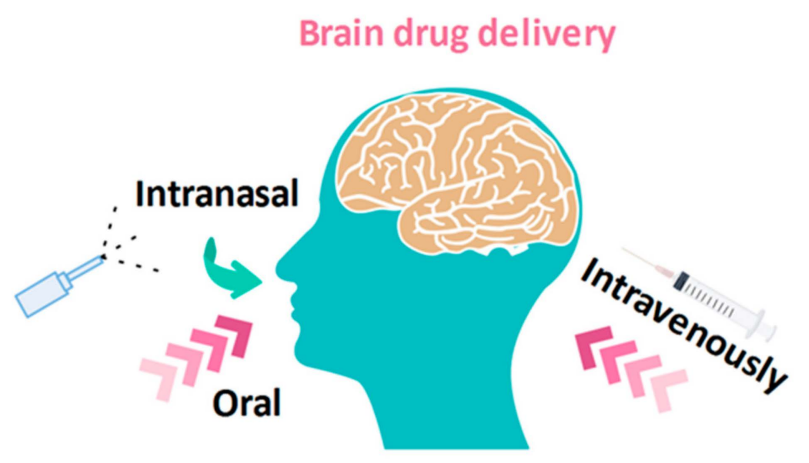

Figure 3. The demand for more effective therapeutics has led to the development of multiple strategies to reach the brain tissue.

The first nasal formulations with a chitosan absorption enhancer to induce the brain's uptake of neuroactive agents were proposed in 2008 [112]. Nasal formulations with the presence of chitosan or its derivatives were prepared as anti-ischemic drugs, anti-Alzheimer's drugs, anxiolytic drugs, anti-Parkinson's drugs, antimigraine drugs, anti-neurodegenerative drugs, antibiotic drugs, anti-nociceptive drugs, antiepileptic drugs and anti-HIV drugs. They have many advantages over liquid preparations: e.g., they are easy to handle, can be used as carriers for protein or other unstable drugs and provide a lengthy residence time of the drug in the nasal cavity. Chitosan may be used in its unmodified form or in the form of chitosan salts or chitosan derivatives. Different chitosan formulations using different preparation techniques and drugs were studied for the treatment of the same neuropathological conditions. Some of them are mentioned here.

The N,N,N-trimethyl chitosan (TMC) is a positively charged, quaternized hydrophilic derivative of chitosan. It has excellent solubility over the entire $\mathrm{pH}$ range compared to chitosan and is completely biodegradable and biocompatible, while possessing greater bioadhesivity than chitosan [115]. It also improves the nasal residence time of the nanocarrier formulation and helps to enhance permeability across the nasal mucosal membrane [116]. It has been used for formulations in different forms, such as neuronanoemulsions (NNEs) or hydrogels.

Ropinirole-dextran sulfate (ROPI-DS) nanocomplex-loaded, flaxseed oil-based NNEs and TMC-modified mNNEs have been developed for direct nose-to-brain drug delivery, with the objective of providing controlled drug release for the treatment of Parkinson's disease (PD). Direct nose-to-brain drug delivery in a mouse model has achieved significantly high drug concentrations in the brain compartment [117]. Furthermore, thermosensitive hydrogel from pluronic F127 (PF127) and TMC was developed as a drug delivery system for the anticancer drug docetaxel (DTX) to glioblastoma multiforme (GBM). With intratumoral drug delivery to the tumor, it is very unlikely to achieve uniform distribution and it has a low retention time. Retention time can be increased by using a hydrogel delivery system for encapsulation of the drug [118]. The addition of TMC to the gel system increased the porosity of the gel network as observed by SEM, and that led to higher release of DTX from the gel. Cytotoxicity data revealed that the hydrogel system can effectively kill cancer cells, in contrast to free DTX [119].

For treatment of $\mathrm{PD}$, pramipexole dihydrochloride-loaded chitosan nanoparticles (P-CNs) were developed in another study for effective brain targeting via the non-invasive nasal route. Nanoparticles were prepared using chitosan and sodium tripolyphosphate by the ionic gelation method. P-CNs significantly enhanced antioxidant status in the form of increased superoxide dismutase and catalase activity, along with increased dopamine levels in the brain [120]. Ropinirole hydrochloride (R-HCl) is a non-ergoline dopamine (D2) receptor agonist used in PD therapy. The conventional oral tablet dosage forms of $\mathrm{R}-\mathrm{HCl}$ available on the market exhibit low oral bioavailability, due to its extensive first-pass metabolism in the stomach after oral administration. A study was done to increase the brain uptake of $\mathrm{R}-\mathrm{HCl}$ through chitosan nanoparticles prepared by a conventional emulsification crosslinking method. 
Coupling nanotechnology with surfactant coating on the chitosan nanoparticles resulted in enhanced brain targeting of the encapsulated drug [121].

The most common neurodegenerative disorder to cause dementia is Alzheimer's disease (AD). Type-2 diabetes (T2D) is one of the major risk factors associated with AD. Similarities have been found in the molecular mechanisms that underlie the respective degenerative development in the two diseases. Saxagliptin (SAX) is a dipeptidyl peptidase-4 enzyme inhibitor molecule explored for its activity in AD therapy. The dipeptidyl peptidase-4 enzyme increases the level of glucagon-like peptide-1 (GLP-1) and ameliorates T2D [122]. Because of its extreme hydrophilicity, SAX is unable to permeate the blood-brain barrier by conventional therapy modalities. Chitosan-L-valine (CSV)-based nanoparticles loaded with SAX were developed, utilizing the large amino acid transporter (LAT-1) at the blood-brain barrier, which helps in the transport of amino acids and amino acid-like molecules into the brain cells. In vivo application of the formulation resulted in enhanced drug delivery in the brain compared to the suspension of SAX, which showed no detectable amount even after $24 \mathrm{~h}$ [123].

A biodegradable chitosan-poly(lactide-co-glycolide) (PLGA) drug was synthesized in the form of a nanoformulation as a therapeutic approach for the delivery of neuroprotective drugs to the brain in the treatment of epilepsy [124], which has been defined as a recurrent and unpredictable set of chronic neurological disorders in the normal brain [125]. L-pGlu-(1-benzyl)-L-His-LProNH2 (NP-355) and L-pGlu-(2-propyl)-L-His-L-ProNH2 (NP-647)-loaded PLGA nanoparticles were prepared and surface modified with chitosan to provide mucoadhesive properties for successful intranasal delivery of drugs to the brain. The in vivo studies showed that recovery was significantly improved after intranasal administration of NP-355 and NP-647 NPs, as compared to un-encapsulated NP-355 and NP-647 [124]. Also, carboxymethyl chitosan nanoparticles as a carrier to deliver carbamazepine (CBZ) (CBZ-NPs) was developed for intranasal administration [126]. CBZ is used in the clinical treatment of seizure disorders, trigeminal neuralgia and, most recently, manic depression. The in vivo results showed that both encapsulation of CBZ in nanoparticles and the nasal route resulted in enhanced drug bioavailability and brain targeting characteristics [127].

Another possibility is to produce lipid microparticles (LMs), coated with chitosan and containing the polyphenol resveratrol. Specifically, for central nervous system diseases, resveratrol has been reported to be effective against neurologic disorders such as AD and PD, brain ischemia and epilepsy. In vivo studies were performed on rats. Such an LMs system attained complete targeting of resveratrol to the CNS via a direct nose-to-CSF route, resveratrol being undetectable in the bloodstream of rats after nasal administration of the chitosan-coated resveratrol-loaded LMs [128]. Recent studies of chitosan formulations for brain uptake of different drugs are presented in Table 5. 
Table 5. Recent studies of chitosan formulations for brain uptake of different drugs.

\begin{tabular}{|c|c|c|c|c|}
\hline & Drug & Disease & Delivery & Ref. \\
\hline Chitosan nanoparticles & Chlorotoxin and transferrin & Brain tumors & Intranasal & [113] \\
\hline Chitosan nanoparticles & Pramipexole & Parkinson's disease & Intranasal & [120] \\
\hline $\begin{array}{l}\text { Flaxseed oil/N,N,N-trimethyl } \\
\text { chitosan neuronanoemulsion }\end{array}$ & Ropinirole-dextran sulfate & Parkinson's disease & Intranasal & [117] \\
\hline $\begin{array}{l}\text { Pluronic F127/N,N,N-trimethyl } \\
\text { chitosan hydrogel system }\end{array}$ & Docetaxel & Malignant glioma & $\begin{array}{l}\text { Intracranial } \\
\text { injection }\end{array}$ & [119] \\
\hline $\begin{array}{l}\text { Chitosan/L-valine } \\
\text {-based nanoparticles }\end{array}$ & Saxagliptin & Alzheimer's disease & $\begin{array}{l}\text { Intraperitoneal } \\
\text { route }\end{array}$ & [123] \\
\hline $\begin{array}{l}\text { Chitosan coated lipid } \\
\text { microparticles }\end{array}$ & Resveratrol & $\begin{array}{l}\text { Central nervous system } \\
\text { diseases }\end{array}$ & $\begin{array}{c}\text { Nasal } \\
\text { administration }\end{array}$ & [128] \\
\hline $\begin{array}{c}\text { Poly-lactide-co-glycolide/chitosan } \\
\text { nanoparticles }\end{array}$ & $\begin{array}{l}\text { L-pGlu-(1-benzyl)-L-His-LProNH2 } \\
\text { and } \\
\text { L-pGlu-(2-propyl)-L-His-L-ProNH2 }\end{array}$ & Epilepsy & Intranasal & [124] \\
\hline Chitosan nanoparticles & Ropinirole hydrochloride & Parkinson's disease & $\begin{array}{l}\text { Intravenously } \\
\text { via the dorsal } \\
\text { tail vein }\end{array}$ & [121] \\
\hline $\begin{array}{c}\text { Carboxymethyl chitosan } \\
\text { nanoparticles }\end{array}$ & Carbamazepine & Epilepsy & Intranasal & [127] \\
\hline $\begin{array}{l}\text { Methoxy poly(ethylene } \\
\text { glycol)-grafted Carboxymethyl } \\
\text { chitosan nanoparticles }\end{array}$ & Doxorubicin & Malignant glioma & & [129] \\
\hline $\begin{array}{l}\text { Poly- } \varepsilon \text {-caprolactone nanocapsules } \\
\text { coated with chitosan }\end{array}$ & Simvastatin & $\begin{array}{l}\text { Brain } \\
\text { tumors }\end{array}$ & Intranasal & [130] \\
\hline $\begin{array}{c}\text { Chitosan-based mucoadhesive } \\
\text { microemulsions }\end{array}$ & Diazepam & Epilepsy & Intranasal & [131] \\
\hline Chitosan nanoparticles & Rotigotine & Parkinson's disease & Intranasal & [132] \\
\hline Chitosan nanoparticles & Genistein & $\begin{array}{l}\text { Neurodegenerative } \\
\text { diseases }\end{array}$ & Intranasal & [133] \\
\hline Chitosan lipid nanoparticles & Risperidone & Schizophrenia & Intranasal & [134] \\
\hline $\begin{array}{l}\text { Nano lipid Vit E mixed with } \\
\text { melted Gelucire 44/ } \\
\text { 14/chitosan hydrogel formulation }\end{array}$ & Temozolomide & $\begin{array}{l}\text { Metastatic melanoma and } \\
\text { glioma }\end{array}$ & Intranasal & [135] \\
\hline $\begin{array}{l}\text { Chitosan-coated liposome } \\
\text { dry-powder formulations }\end{array}$ & Ghrelin & Cachexia & Intranasal & [136] \\
\hline Chitosan nanoparticles & Cyclovirobuxine D & Cardiovascular disease & Intranasal & [137] \\
\hline $\begin{array}{c}\text { Chitosan glutamate coated } \\
\text { niosomes }\end{array}$ & Pentamidine & Alzheimer's disease & Intranasal & [138] \\
\hline $\begin{array}{l}\text { Glycol chitosan coated } \\
\text { nanostructured lipid carrier }\end{array}$ & Asenapine maleate & $\begin{array}{l}\text { Schizophrenia and bipolar } \\
\text { disorders }\end{array}$ & Intranasal & [139] \\
\hline $\begin{array}{l}\text { Nasal chitosan } \\
\text { microspheres }\end{array}$ & Hydroxypropyl-cyclodextrin & Alzheimer's disease & Nasal route & [140] \\
\hline $\begin{array}{l}\text { Chitosan oligosaccharide } \\
\text { Chitosan-grafted }\end{array}$ & Chitosan oligosaccharide lactate & Depression & & [141] \\
\hline $\begin{array}{l}\mathrm{HPbCD} \text { intranasal EFV } \\
\text { nanoparticles }\end{array}$ & Efavirenz & Neuro-AIDS & Intranasal & [142] \\
\hline
\end{tabular}

\subsection{Other Biomedical Applications}

Chitosan formulations as drug delivery carriers are not limited to delivering active agents to the brain, but can be used for many other delivery purposes in biomedicine. As mentioned before, the low solubility of chitosan in biological systems limits its use as a drug delivery carrier [110]. Therefore, derivation of chitosan to improve its hydrophilicity is a promising path. A glycol-chitosan-based carrier is suitable and most popular for drug delivery in biological systems, owing to its water solubility and biocompatibility $[143,144]$. On the other hand, chitosan is also insoluble in most organic solvents, and is therefore inappropriate as a carrier for hydrophobic drugs [145]. To overcome this deficiency of chitosan, various derivation methods were developed to increase the encapsulation efficiency of hydrophobic components. When release of a drug cannot be performed by using simple drug dissolution processes such as diffusion, in anionic drug delivery systems, anionic polymeric excipients (e.g., chitosan) can be used. The mucoadhesive nature of chitosan and its ability to temporarily open tight epithelial junctions allow its application in drug delivery systems for different epithelia [146,147]. Mucosal surfaces are the most common and convenient routes for delivering drugs to the body. However, macromolecular drugs, such as peptides and proteins, are unable to overcome the mucosal barriers, since they are usually degraded before reaching the bloodstream. To overcome this problem, the use of nanostructures based on the mucoadhesive polysaccharide chitosan is a promising alternative [148]. 
Chitosan-based nanoparticles have several advantages that place them among the potential carriers for genes and other nucleic acid delivery systems. Because of the positive charge of chitosan, interaction with negatively charged nucleic acid molecules forms a polyelectrolyte complex [149], which protects nucleic acids from degradation caused by nuclease [150]. Various methods have been reported for the preparation of chitosan-based protein-loaded particles. The most commonly used preparation method is emulsification with cross-linking, where the use of organic solvents and crosslinkers can negatively affect protein activity [148].

To improve the protein-sponging ability of chitosan, a variety of methods has been used-e.g., incorporation of different moieties (imidazole [149] histidine [151] etc.). Chitosan has been used to transfect a range of different cell types in vitro and in vivo. In vitro, the most commonly used cell lines that have been transfected using chitosan-pDNA complexes are HEK293, A549, HeLa and COS-1 [152]. Additionally, chitosan was successfully used as a carrier of RNAi in chitosan-RNAi complexes for transfection of CHO-K1, HEK293, H1299 and HepG2 cells [152]. Gene therapeutics can be delivered in a number of ways for clinical translation [153], but innovative methods involved the incorporation of complexes into a scaffold, with the aim of spreading them to the defective site [154,155].

Chitosan and chitosan nanocomposites have also been used in bioimaging, biomedical devices, sensors, etc. Darder at al. [156] reported that chitosan-montmorillonite nanocomposites constitute excellent materials for the development of bulk-modified potentiometric sensors for anionic detection in aqueous samples. A graphene/AuNPs/chitosan electrode showed high electrocatalytic activity toward $\mathrm{H}_{2} \mathrm{O}_{2}$ and $\mathrm{O}_{2}$ and could be used for the construction of a glucose biosensor [157]. A GOx- O-(2-hydroxyl) propyl-3-trimethylammonium chitosan chloride NP-conjugated anion membrane biosensor showed good sensitivity, reproducibility, reusability, low cost and an easy-to-operate system for quantification of glucose in the system [158]. Shakya and Nandakuma [159] prepared the Au-GOx-based glucose sensor, which showed good stability for up to 30 days, with high sensitivity $\left(8.91 \mu \mathrm{A} \mathrm{mM} \mathrm{m}^{-1} \mathrm{~cm}^{-2}\right)$ and fast response times. Palladium nanoparticles modified with chitosan oligosaccharide (COS) were functionalized with RGD peptide, which improves particle accumulation in MDA-MB-231 breast cancer cells and results in enhanced photothermal therapeutic effects under an 808-nm laser. The RGD peptide-linked, COS-coated palladium nanoparticles (Pd@COS-RGD) destroyed the tumor effectively under 808-nm laser illumination at a power density of $2 \mathrm{~W} \mathrm{~cm}^{-2}$. They act as an ideal nanotheranostic agent for enhanced imaging of and therapy for tumors using a non-invasive near-infrared laser [160]. Karagozlu et al. [161] reported that QMW-chitosan oligomers and WMQ-chitosan oligomers $(\mathrm{Q}$, - glutamine $\mathrm{M}$-methionine and W - tryptophan) exerted a protective action on C8166 cells against the cytolytic effects of an HIV-1RF strain. Additionally, the saquinavir-loaded chitosan nanoparticles indicated the potency of the system as an effective anti-HIV system, since both strains of HIV - NL4-3 and Indie-C1 were found to respond to the saquinavir -chitosan delivery system [162]. Many of these emerging biochemical applications, including chitosan-based nanomaterials, are presented in Table 6. 
Table 6. Selected emerging chitosan-based biomedical applications.

\begin{tabular}{|c|c|c|c|}
\hline Matrix & Biomedical Application & Findings & Ref. \\
\hline $\begin{array}{l}\text { Zinc-chitosan } \\
\text { nanoparticles }\end{array}$ & $\begin{array}{l}\text { Treatment of acute } \\
\text { lymphoblastic leukemia }\end{array}$ & $\begin{array}{l}\text { Induced apoptosis in human acute } \\
\text { T-lymphocyte leukemia through } \\
\text { activation of tumor necrosis factor } \\
\text { receptor CD95 }\end{array}$ & [163] \\
\hline $\begin{array}{l}\text { Sodium alginate beads } \\
\text { with olive oil and coating } \\
\text { with chitosan }\end{array}$ & $\begin{array}{l}\text { Helicobacter pylori } \\
\text { infections }\end{array}$ & $\begin{array}{l}\text { Controlled release of active } \\
\text { Clarithromycin }\end{array}$ & [164] \\
\hline $\begin{array}{l}\text { Timolol maleate-loaded } \\
\text { galactosylated chitosan } \\
\text { nanoparticles }\end{array}$ & $\begin{array}{l}\text { Ocular delivery of } \\
\text { timolol maleate }\end{array}$ & $\begin{array}{l}\text { In vitro transcorneal permeation } \\
\text { study and confocal microscopy } \\
\text { showed enhanced penetration, } \\
\text { and retention in the cornea }\end{array}$ & [165] \\
\hline $\begin{array}{l}\text { Modified glycol chitosan } \\
\text { nanoparticles } \\
\text { encapsulated } \\
\text { camptothecin }\end{array}$ & Cancer therapy & $\begin{array}{l}\text { Stable and effective drug delivery } \\
\text { system in cancer therapy }\end{array}$ & [166] \\
\hline $\begin{array}{l}\text { Insulin-loaded } \\
\text { lecithin/chitosan } \\
\text { nanoparticles }\end{array}$ & $\begin{array}{l}\text { Drug delivery system to } \\
\text { the deep lung }\end{array}$ & $\begin{array}{l}\text { Improved oral bioavailability, } \\
\text { time-dependent release, and } \\
\text { therapeutic activity }\end{array}$ & [167] \\
\hline $\begin{array}{l}\text { Chitosan grafted } \\
\text { poly(ethylene glycol) } \\
\text { methacrylate }\end{array}$ & Posterior eye diseases & $\begin{array}{l}\text { Particles were found suitable from } \\
\text { the cytotoxicity and } \\
\text { hemocompatibility points of view }\end{array}$ & [168] \\
\hline $\begin{array}{l}\text { Palladium nanoparticles } \\
\text { chitosan oligosaccharide } \\
\text { (COS) functionalized } \\
\text { with RGD peptide }\end{array}$ & $\begin{array}{l}\text { Breast cancer therapy by } \\
\text { imaging }\end{array}$ & $\begin{array}{c}\text { Matrix acts as an ideal } \\
\text { nanotheranostic agent for } \\
\text { enhanced imaging and tumor } \\
\text { therapy, using a non-invasive } \\
\text { near-infrared laser }\end{array}$ & [160] \\
\hline $\begin{array}{l}\text { Graphene/AuNPs/chitosan } \\
\text { electrode }\end{array}$ & $\begin{array}{c}\text { Construction of a glucose } \\
\text { biosensor }\end{array}$ & $\begin{array}{l}\text { High electrocatalytic activity } \\
\text { toward } \mathrm{H}_{2} \mathrm{O}_{2} \text { and } \mathrm{O}_{2}\end{array}$ & [157] \\
\hline $\begin{array}{l}\text { Chitosan-RNAi } \\
\text { complexes }\end{array}$ & Gene therapy & $\begin{array}{c}\text { Transfection of CHO-K1, HEK293, } \\
\text { H1299, HepG2 cells }\end{array}$ & [152] \\
\hline $\begin{array}{l}\text { Chitosan-montmorillonite } \\
\text { nanocomposites }\end{array}$ & Biomedical sensors & $\begin{array}{l}\text { Bulk-modified potentiometric } \\
\text { sensors for anionic detection in } \\
\text { aqueous samples }\end{array}$ & [156] \\
\hline Chitosan-Au particles & $\begin{array}{l}\text { Biomedical sensors to } \\
\text { detect DNA }\end{array}$ & Low cost of preparation & [169] \\
\hline $\begin{array}{l}\text { Saquinavir-loaded } \\
\text { chitosan nanoparticles }\end{array}$ & $\begin{array}{l}\text { Effective anti-HIV } \\
\text { system }\end{array}$ & $\begin{array}{l}\text { Strains of HIV - NL4-3 and } \\
\text { Indie-C1 were found to respond to } \\
\text { delivery system }\end{array}$ & [162] \\
\hline $\begin{array}{l}\text { Magnetic chitin } \\
\text { nanofiber composite }\end{array}$ & $\begin{array}{l}\text { Immobilization of } \\
\text { therapeutic enzyme }\end{array}$ & $\begin{array}{l}\text { Immobilized chymotrypsin could } \\
\text { be easily separated and recycled } \\
\text { from the reaction system by } \\
\text { magnetic force }\end{array}$ & [170] \\
\hline
\end{tabular}

\section{Conclusions and Future Trends}

Chitosan is one of the most abundant polysaccharide polymers, and is capable of significant antimicrobial activity against a wide variety of fungi and bacteria. Despite many proposed hypotheses and contributing effects, there is no consensus on the mechanism of action for its antimicrobial activity. This could be explained by the fact that, in most studies, the assay conditions have not been standardized and it is thus difficult to make a good comparison between them. The most widely accepted hypothesis is that positively-charged amine groups $\left(\mathrm{NH}_{3}{ }^{+}\right)$of glucosamine interact with the negatively charged surface of bacteria, causing leakage of intracellular constituents that results in cell death.

In the present review, chitosan has been presented as an ideal renewable agent for the fabrication of antimicrobial wound dressings, either alone in its native form or upgraded and incorporated with antibiotics, metallic antimicrobial particles, natural compounds and extracts. The incorporation of 
metallic nanoparticles into chitosan-based matrices has been reported as a novel idea to increase and sustain antimicrobial effect. Prior to clinical application in vivo, the toxicity of nanoparticles still needs to be solved. There has been no effort made to fully evaluate its efficiency in an infectious area in vivo and in vitro. Similarly, there are many opportunities for future studies of chitosan use in combination with natural compounds and extracts. Further improvement to chitosan-based wound dressings are also needed. These include development of new smart dressings containing sensors and therapeutic molecules that are released at the same time as the microbial growth. In this concept, a wound dressing system releases bioactive compounds when any change in the medium occurs, including $\mathrm{pH}$, temperature or UV due to initial bacterial activity.

Brain drug delivery is another biomedical application where chitosan and its derivatives as nano-biodegradable carriers play an important role. A wide variety of chitosan-based nanoparticles has proven to improve the therapeutic efficacy in various brain diseases, owing to its fine biological properties, modifiability and effective uptake by intranasal mucosal cells to tumor cells. There are still challenges to solve regarding the toxicity of some chitosan derivatives, which could serve as carriers of material for nose-to-brain drug delivery. Moreover, in the case of chitosan and protein complexes, the interaction between polysaccharides and proteins, the phase behavior and colloidal properties of complexes between chitosan, a positively-charged polysaccharide, and proteins still need to be investigated. In acidic $\mathrm{pH}$, chitosan is highly protonated, which stabilizes the complexes. Furthermore, the addition of $\mathrm{NaCl}$ leads to a reduction in both size and zeta-potential and facilitates complex aggregation.

In conclusion, chitosan-based nanomaterials are often present in today's clinical applications and are expected to have an even greater impact on emerging biomedical applications.

Author Contributions: M.L. and G.K. conceived and designed the review. M.L., G.K. and M.P. studied the literature and wrote the manuscript. Ž.K. verified the manuscript. All authors accepted the final version of the review.

Funding: This research was supported by the Slovenian Research Agency (ARRS) within the frame of program P2-0046 (Separation Processes and Production Design).

Conflicts of Interest: The authors declare no conflicts of interest.

\section{References}

1. Elgadir, M.A.; Uddin, M.S.; Ferdosh, S.; Adam, A.; Chowdhury, A.J.K.; Sarker, M.Z.I. Impact of chitosan composites and chitosan nanoparticle composites on various drug delivery systems: A review. J. Food Drug Anal. 2015, 23, 619-629. [CrossRef] [PubMed]

2. Pang, Y.; Qin, A.; Lin, X.; Yang, L.; Wang, Q.; Wang, Z.; Shan, Z.; Li, S.; Wang, J.; Fan, S. Biodegradable and biocompatible high elastic chitosan scaffold is cell-friendly both in vitro and in vivo. Oncotarget 2017, 8, 35583. [CrossRef] [PubMed]

3. Gallaher, C.M.; Munion, J.; Hesslink Jr, R.; Wise, J.; Gallaher, D.D. Cholesterol reduction by glucomannan and chitosan is mediated by changes in cholesterol absorption and bile acid and fat excretion in rats. J. Nutr. 2000, 130, 2753-2759. [CrossRef] [PubMed]

4. Liu, J.; Meng, C.-g.; Liu, S.; Kan, J.; Jin, C.-h. Preparation and characterization of protocatechuic acid grafted chitosan films with antioxidant activity. Food Hydrocoll. 2017, 63, 457-466. [CrossRef]

5. Goy, R.C.; Britto, D.d.; Assis, O.B. A review of the antimicrobial activity of chitosan. Polímeros 2009, 19, 241-247. [CrossRef]

6. Fei Liu, X.; Lin Guan, Y.; Zhi Yang, D.; Li, Z.; De Yao, K. Antibacterial action of chitosan and carboxymethylated chitosan. J. Appl. Polym. Sci. 2001, 79, 1324-1335. [CrossRef]

7. Vinsova, J.; Vavrikova, E. Chitosan derivatives with antimicrobial, antitumour and antioxidant activities-A review. Curr. Pharm. Des. 2011, 17, 3596-3607. [CrossRef]

8. Jayakumar, R.; Prabaharan, M.; Kumar, P.S.; Nair, S.; Tamura, H. Biomaterials based on chitin and chitosan in wound dressing applications. Biotechnol. Adv. 2011, 29, 322-337. [CrossRef] 
9. Li, J.; Cai, C.; Li, J.; Li, J.; Li, J.; Sun, T.; Wang, L.; Wu, H.; Yu, G. Chitosan-Based Nanomaterials for Drug Delivery. Molecules 2018, 23, 2661. [CrossRef]

10. Chuan, D.; Jin, T.; Fan, R.; Zhou, L.; Guo, G. Chitosan for gene delivery: Methods for improvement and applications. Adv. Coll. Int. Sci. 2019, 268, 25-38. [CrossRef] [PubMed]

11. Hu, Z.; Lu, S.; Cheng, Y.; Kong, S.; Li, S.; Li, C.; Yang, L. Investigation of the Effects of Molecular Parameters on the Hemostatic Properties of Chitosan. Molecules 2018, 23, 3147. [CrossRef]

12. Husain, S.; Al-Samadani, K.H.; Najeeb, S.; Zafar, M.S.; Khurshid, Z.; Zohaib, S.; Qasim, S.B. Chitosan biomaterials for current and potential dental applications. Materials 2017, 10, 602. [CrossRef] [PubMed]

13. Wahba, M.I. Sodium bicarbonate-gelled chitosan beads as mechanically stable carriers for the covalent immobilization of enzymes. Biotechnol. Prog. 2018, 34, 347-361. [CrossRef] [PubMed]

14. Sudarshan, N.; Hoover, D.; Knorr, D. Antibacterial action of chitosan. Food Biotechnol. 1992, 6, 257-272. [CrossRef]

15. Varma, A.; Deshpande, S.; Kennedy, J. Metal complexation by chitosan and its derivatives: A review. Carbohydr. Polym. 2004, 55, 77-93. [CrossRef]

16. Severino, R.; Ferrari, G.; Vu, K.D.; Donsì, F.; Salmieri, S.; Lacroix, M. Antimicrobial effects of modified chitosan based coating containing nanoemulsion of essential oils, modified atmosphere packaging and gamma irradiation against Escherichia coli O157: H7 and Salmonella Typhimurium on green beans. Food Cont. 2015, 50, 215-222. [CrossRef]

17. Rabea, E.I.; Badawy, M.E.-T.; Stevens, C.V.; Smagghe, G.; Steurbaut, W. Chitosan as antimicrobial agent: Applications and mode of action. Biomacromolecules 2003, 4, 1457-1465. [CrossRef]

18. Li, Z.; Yang, F.; Yang, R. Synthesis and characterization of chitosan derivatives with dual-antibacterial functional groups. Int. J. Biol. Macromol. 2015, 75, 378-387. [CrossRef]

19. Roy, K.; Mao, H.-Q.; Huang, S.-K.; Leong, K.W. Oral gene delivery with chitosan-DNA nanoparticles generates immunologic protection in a murine model of peanut allergy. Nat. Med. 1999, 5, 387. [CrossRef]

20. Wang, X.; Du, Y.; Fan, L.; Liu, H.; Hu, Y. Chitosan-metal complexes as antimicrobial agent: Synthesis, characterization and structure-activity study. Polym. Bull. 2005, 55, 105-113. [CrossRef]

21. Dutta, P.; Tripathi, S.; Mehrotra, G.; Dutta, J. Perspectives for chitosan based antimicrobial films in food applications. Food Chem. 2009, 114, 1173-1182. [CrossRef]

22. Devlieghere, F.; Vermeulen, A.; Debevere, J. Chitosan: Antimicrobial activity, interactions with food components and applicability as a coating on fruit and vegetables. Food Microbiol. 2004, 21, 703-714. [CrossRef]

23. Yuan, G.; Lv, H.; Tang, W.; Zhang, X.; Sun, H. Effect of chitosan coating combined with pomegranate peel extract on the quality of Pacific white shrimp during iced storage. Food Control. 2016, 59, 818-823. [CrossRef]

24. Aiedeh, K.; Taha, M.O. Synthesis of iron-crosslinked chitosan succinate and iron-crosslinked hydroxamated chitosan succinate and their in vitro evaluation as potential matrix materials for oral theophylline sustained-release beads. Eur. J. Pharm. Sci. 2001, 13, 159-168. [CrossRef]

25. Sahariah, P.; Maásson, M.r. Antimicrobial chitosan and chitosan derivatives: A review of the structure-activity relationship. Biomacromolecules 2017, 18, 3846-3868. [CrossRef]

26. No, H.K.; Young Park, N.; Ho Lee, S.; Meyers, S.P. Antibacterial activity of chitosans and chitosan oligomers with different molecular weights. Int. J. Food Microbiol. 2002, 74, 65-72. [CrossRef]

27. Takahashi, T.; Imai, M.; Suzuki, I. Water permeability of chitosan membrane involved in deacetylation degree control. Biochem. Engin. J. 2007, 36, 43-48. [CrossRef]

28. Hosseinnejad, M.; Jafari, S.M. Evaluation of different factors affecting antimicrobial properties of chitosan. Int. J. Biol. Macromol. 2016, 85, 467-475. [CrossRef]

29. Byun, S.M.; No, H.K.; Hong, J.H.; Lee, S.I.; Prinyawiwatkul, W. Comparison of physicochemical, binding, antioxidant and antibacterial properties of chitosans prepared from ground and entire crab leg shells. Int. J. Food Sci. Technol. 2013, 48, 136-142. [CrossRef]

30. Kong, M.; Chen, X.G.; Xing, K.; Park, H.J. Antimicrobial properties of chitosan and mode of action: A state of the art review. Int. J. Food Microbiol. 2010, 144, 51-63. [CrossRef]

31. Younes, I.; Sellimi, S.; Rinaudo, M.; Jellouli, K.; Nasri, M. Influence of acetylation degree and molecular weight of homogeneous chitosans on antibacterial and antifungal activities. Int. J. Food Microbiol. 2014, 185, 57-63. [CrossRef] [PubMed]

32. Plapied, L.; Vandermeulen, G.; Vroman, B.; Préat, V.; des Rieux, A. Bioadhesive nanoparticles of fungal chitosan for oral DNA delivery. Int. J. Pharm. 2010, 398, 210-218. [CrossRef] [PubMed] 
33. Ing, L.Y.; Zin, N.M.; Sarwar, A.; Katas, H. Antifungal Activity of Chitosan Nanoparticles and Correlation with Their Physical Properties. Int. J. Biomater. 2012, 2012, 9. [CrossRef]

34. Muzzarelli, R.A.A. Chitosan-based dietary foods. Carbohydr. Polym. 1996, 29, 309-316. [CrossRef]

35. Roller, S.; Covill, N. The antifungal properties of chitosan in laboratory media and apple juice. Int. J. Food Microbiol. 1999, 47, 67-77. [CrossRef]

36. No, H.K.; Kim, S.H.; Lee, S.H.; Park, N.Y.; Prinyawiwatkul, W. Stability and antibacterial activity of chitosan solutions affected by storage temperature and time. Carbohydr. Polym. 2006, 65, 174-178. [CrossRef]

37. Li, X.-f.; Feng, X.-q.; Yang, S.; Fu, G.-q.; Wang, T.-p.; Su, Z.-x. Chitosan kills Escherichia coli through damage to be of cell membrane mechanism. Carbohydr. Polym. 2010, 79, 493-499. [CrossRef]

38. Kulikov, S.N.; Tikhonov, V.E.; Bezrodnykh, E.A.; Lopatin, S.A.; Varlamov, V.P. Comparative evaluation of antimicrobial activity of oligochitosans against Klebsiella pneumoniae. Rus. J. Bioorg. Chem. 2015, 41, 57-62. [CrossRef]

39. Kong, M.; Chen, X.-G.; Xue, Y.-P.; Liu, C.-S.; Yu, L.-J.; Ji, Q.-X.; Cha, D.S.; Park, H.J. Preparation and antibacterial activity of chitosan microshperes in a solid dispersing system. Front. Mater. Sci. China 2008, 2, 214-220. [CrossRef]

40. Takahashi, T.; Imai, M.; Suzuki, I.; Sawai, J. Growth inhibitory effect on bacteria of chitosan membranes regulated with deacetylation degree. Biochem. Engin. J. 2008, 40, 485-491. [CrossRef]

41. Raafat, D.; Von Bargen, K.; Haas, A.; Sahl, H.-G. Insights into the mode of action of chitosan as an antibacterial compound. Appl. Environ. Microbiol. 2008, 74, 3764-3773. [CrossRef]

42. Ziani, K.; Fernández-Pan, I.; Royo, M.; Maté, J.I. Antifungal activity of films and solutions based on chitosan against typical seed fungi. Food Hydrocoll. 2009, 23, 2309-2314. [CrossRef]

43. Mellegård, H.; Strand, S.; Christensen, B.; Granum, P.; Hardy, S. Antibacterial activity of chemically defined chitosans: Influence of molecular weight, degree of acetylation and test organism. Int. J. Food Microbiol. 2011, 148, 48-54. [CrossRef]

44. Tsai, G.J.; Su, W.H.; Chen, H.C.; Pan, C.L. Antimicrobial activity of shrimp chitin and chitosan from different treatments and applications of fish preservation. Fish. Sci. 2002, 68, 170-177. [CrossRef]

45. Sivashankari, P.; Prabaharan, M. Prospects of chitosan-based scaffolds for growth factor release in tissue engineering. Int. J. Biol. Macromol. 2016, 93, 1382-1389. [CrossRef]

46. Misgav, M.; Lubetszki, A.; Brutman-Barazani, T.; Martinowitz, U.; Kenet, G. The hemostatic efficacy of chitosan-pads in hemodialysis patients with significant bleeding tendency. J. Vasc. Access 2017, 18, 220-224. [CrossRef]

47. Ahmed, T.A.; Aljaeid, B.M. Preparation, characterization, and potential application of chitosan, chitosan derivatives, and chitosan metal nanoparticles in pharmaceutical drug delivery. Drug Des. Dev. Ther. 2016, 10, 483. [CrossRef]

48. Yang, H.; Chen, Y.; Chen, Z.; Geng, Y.; Xie, X.; Shen, X.; Li, T.; Li, S.; Wu, C.; Liu, Y. Chemo-photodynamic combined gene therapy and dual-modal cancer imaging achieved by $\mathrm{pH}$-responsive alginate/chitosan multilayer-modified magnetic mesoporous silica nanocomposites. Biomater. Sci. 2017, 5, 1001-1013. [CrossRef]

49. Sengiz, C.; Congur, G.; Eksin, E.; Erdem, A. Multiwalled carbon nanotubes-chitosan modified single-use biosensors for electrochemical monitoring of drug-DNA interactions. Electroanalysis 2015, 27, 1855-1863. [CrossRef]

50. Lee, H.; Kim, M.; Yoon, Y.; Park, W. Fluorescent property of chitosan oligomer and its application as a metal ion sensor. Mar. Drugs 2017, 15, 105. [CrossRef]

51. Rodrigues, S.V.; John, L.E.; Mitra, D.K.; Shah, R.; Shetty, G.; Prithyani, S.; Vijayakar, H. Evaluation and Comparison of Antimicrobial Effects of Chlorhexidine (CHX) and Chitosan (CHT) Mouthwash in Chronic Periodontitis (CGP) Patients-A Clinico-microbiological Study. JIDA J. Indian Dent. Assoc. 2018, 16, $26-32$.

52. Bano, I.; Arshad, M.; Yasin, T.; Ghauri, M.A.; Younus, M. Chitosan: A potential biopolymer for wound management. Int. J. Biol. Macromol. 2017, 102, 380-383. [CrossRef]

53. Dekoninck, S.; Blanpain, C. Stem cell dynamics, migration and plasticity during wound healing. Nat. Cell Biol. 2019, 21, 18. [CrossRef]

54. Simões, D.; Miguel, S.P.; Ribeiro, M.P.; Coutinho, P.; Mendonça, A.G.; Correia, I.J. Recent advances on antimicrobial wound dressing: A review. Eur. J. Pharm. Biopharm. 2018, 127, 130-141. [CrossRef]

55. Yang, L.; Lu, W.; Pang, Y.; Huang, X.; Wang, Z.; Qin, A.; Hu, Q. Fabrication of a novel chitosan scaffold with asymmetric structure for guided tissue regeneration. RSC Adv. 2016, 6, 71567-71573. [CrossRef] 
56. Ahmadi, F.; Oveisi, Z.; Samani, S.M.; Amoozgar, Z. Chitosan based hydrogels: Characteristics and pharmaceutical applications. Res. Pharm. Sci. 2015, 10,1.

57. Huang, X.; Sun, Y.; Nie, J.; Lu, W.; Yang, L.; Zhang, Z.; Yin, H.; Wang, Z.; Hu, Q. Using absorbable chitosan hemostatic sponges as a promising surgical dressing. Int. J. Biol. Macromol. 2015, 75, 322-329. [CrossRef]

58. Mi, F.-L.; Shyu, S.-S.; Wu, Y.-B.; Lee, S.-T.; Shyong, J.-Y.; Huang, R.-N. Fabrication and characterization of a sponge-like asymmetric chitosan membrane as a wound dressing. Biomaterials 2001, 22, 165-173. [CrossRef]

59. Coma, V.; Martial-Gros, A.; Garreau, S.; Copinet, A.; Salin, F.; Deschamps, A. Edible antimicrobial films based on chitosan matrix. J. Food Sci. 2002, 67, 1162-1169. [CrossRef]

60. Hoffman, A.S. Hydrogels for biomedical applications. Adv. Drug Deliv. Rev. 2012, 64, 18-23. [CrossRef]

61. Jones, A.; Vaughan, D. Hydrogel dressings in the management of a variety of wound types: A review. J. Orthop. Nurs. 2005, 9, S1-S11. [CrossRef]

62. Mori, M.; Rossi, S.; Ferrari, F.; Bonferoni, M.C.; Sandri, G.; Chlapanidas, T.; Torre, M.L.; Caramella, C. Sponge-like dressings based on the association of chitosan and sericin for the treatment of chronic skin ulcers. I. Design of experiments-assisted development. J. Pharm. Sci. 2016, 105, 1180-1187. [CrossRef]

63. Zhang, D.; Zhou, W.; Wei, B.; Wang, X.; Tang, R.; Nie, J.; Wang, J. Carboxyl-modified poly (vinyl alcohol)crosslinked chitosan hydrogel films for potential wound dressing. Carbohydr. Polym. 2015, 125, 189-199. [CrossRef]

64. Dhivya, S.; Padma, V.V.; Santhini, E. Wound dressings-a review. BioMedicine 2015, 5, 22. [CrossRef] [PubMed]

65. Patrick, G.L. An Introduction to Medicinal Chemistry; Oxford University Press: New York, NY, USA, 2013. [CrossRef]

66. Bermingham, A.; Derrick, J.P. The folic acid biosynthesis pathway in bacteria: Evaluation of potential for antibacterial drug discovery. Bioessays 2002, 24, 637-648. [CrossRef]

67. Hong, W.; Zeng, J.; Xie, J. Antibiotic drugs targeting bacterial RNAs. Acta Pharm. Sin. B 2014, 4, $258-265$. [CrossRef]

68. Madhumathi, K.; Kumar, P.S.; Abhilash, S.; Sreeja, V.; Tamura, H.; Manzoor, K.; Nair, S.; Jayakumar, R. Development of novel chitin/nanosilver composite scaffolds for wound dressing applications. J. Mater. Sci. Mater. Med. 2010, 21, 807-813. [CrossRef]

69. Gliga, A.R.; Skoglund, S.; Wallinder, I.O.; Fadeel, B.; Karlsson, H.L. Size-dependent cytotoxicity of silver nanoparticles in human lung cells: The role of cellular uptake, agglomeration and Ag release. Part. Fibre Toxicol. 2014, 11, 11. [CrossRef]

70. Travan, A.; Pelillo, C.; Donati, I.; Marsich, E.; Benincasa, M.; Scarpa, T.; Semeraro, S.; Turco, G.; Gennaro, R.; Paoletti, S. Non-cytotoxic silver nanoparticle-polysaccharide nanocomposites with antimicrobial activity. Biomacromolecules 2009, 10, 1429-1435. [CrossRef]

71. Zewde, B.; Ambaye, A.; Stubbs III, J.; Dharmara, R. A review of stabilized silver nanoparticles-Synthesis, biological properties, characterization, and potential areas of applications. JSM Nanotechnol. Nanomed. 2016, 4, 1-14.

72. Anisha, B.S.; Biswas, R.; Chennazhi, K.P.; Jayakumar, R. Chitosan-hyaluronic acid/nano silver composite sponges for drug resistant bacteria infected diabetic wounds. Int. J. Biol. Macromol. 2013, 62, 310-320. [CrossRef]

73. Mohandas, A.; Deepthi, S.; Biswas, R.; Jayakumar, R. Chitosan based metallic nanocomposite scaffolds as antimicrobial wound dressings. Bioact. Mater. 2018, 3, 267-277. [CrossRef] [PubMed]

74. Sahnoun, Z.; Bardaa, S.; Rebaï, T. The Effect of Natural Extracts on Laser Burn Wound Healing. In Recent Clinical Techniques, Results, and Research in Wounds; Springer: Cham, Switzerland, 2018; Volume 201, pp. 464-472.

75. Saleem, M.; Nazir, M.; Ali, M.S.; Hussain, H.; Lee, Y.S.; Riaz, N.; Jabbar, A. Antimicrobial natural products: An update on future antibiotic drug candidates. Nat. Prod. Rep. 2010, 27, 238-254. [CrossRef] [PubMed]

76. Wani, M.Y.; Hasan, N.; Malik, M.A. Chitosan and Aloe vera: Two gifts of nature. J. Dispers. Sci. Technol. 2010, 31, 799-811. [CrossRef]

77. Silva, S.S.; Caridade, S.G.; Mano, J.F.; Reis, R.L. Effect of crosslinking in chitosan/aloe vera-based membranes for biomedical applications. Carbohydr. Polym. 2013, 98, 581-588. [CrossRef]

78. Nguyen, V.C.; Nguyen, V.B.; Hsieh, M.-F. Curcumin-Loaded Chitosan/Gelatin Composite Sponge for Wound Healing Application. Int. J. Polym. Sci. 2013, 2013, 7. [CrossRef]

79. Brudzynski, K.; Miotto, D.; Kim, L.; Sjaarda, C.; Maldonado-Alvarez, L.; Fukś, H. Active macromolecules of honey form colloidal particles essential for honey antibacterial activity and hydrogen peroxide production. Sci. Rep. 2017, 7, 7637. [CrossRef] 
80. Qu, Y.; McGiffin, D.; Kure, C.; McLean, J.; Duncan, C.; Peleg, A. A Comprehensive In Vitro Evaluation of Medihoney as an Anti-Biofilm Agent in Preventing Ventricular Assist Device Driveline Infections. J. Heart Lung. Transplant. 2019, 38, S101. [CrossRef]

81. Morgan, T. The use of Actilite Protectßas an all-round wound care solution. Commun. Nurs. 2015, 29, 61-65.

82. Stephen-Haynes, J.; Gibson, E.; Greenwood, M. Chitosan: A natural solution for wound healing. J. Community Nurs. 2014, 28, 48-53.

83. Scagnelli, A.M. Therapeutic review: Manuka honey. J. Exotic Pet. Med. 2016, 25, 168-171. [CrossRef]

84. Adeli, H.; Khorasani, M.T.; Parvazinia, M. Wound dressing based on electrospun PVA/chitosan/starch nanofibrous mats: Fabrication, antibacterial and cytocompatibility evaluation and in vitro healing assay. Int. J. Biol. Macromol. 2019, 122, 238-254. [CrossRef]

85. Flores, C.; Lopez, M.; Tabary, N.; Neut, C.; Chai, F.; Betbeder, D.; Herkt, C.; Cazaux, F.; Gaucher, V.; Martel, B.; et al. Preparation and characterization of novel chitosan and $\beta$-cyclodextrin polymer sponges for wound dressing applications. Carbohydr. Polym. 2017, 173, 535-546. [CrossRef]

86. Li, P.; Poon, Y.F.; Li, W.; Zhu, H.-Y.; Yeap, S.H.; Cao, Y.; Qi, X.; Zhou, C.; Lamrani, M.; Beuerman, R.W.; et al. A polycationic antimicrobial and biocompatible hydrogel with microbe membrane suctioning ability. Nat. Mater. 2010, 10, 149. [CrossRef]

87. Poonguzhali, R.; Basha, S.K.; Kumari, V.S. Synthesis and characterization of chitosan-PVP-nanocellulose composites for in-vitro wound dressing application. Int. J. Biol. Macromol. 2017, 105, 111-120. [CrossRef]

88. Smith, J.K.; Bumgardner, J.D.; Courtney, H.S.; Smeltzer, M.S.; Haggard, W.O. Antibiotic-loaded chitosan film for infection prevention: A preliminary in vitro characterization. J. Biomed. Mater. Res. Part. B Appl. Biomater. 2010, 94, 203-211. [CrossRef]

89. Monteiro, N.; Martins, M.; Martins, A.; Fonseca, N.A.; Moreira, J.N.; Reis, R.L.; Neves, N.M. Antibacterial activity of chitosan nanofiber meshes with liposomes immobilized releasing gentamicin. Acta Biomater. 2015, 18, 196-205. [CrossRef]

90. Siafaka, P.I.; Zisi, A.P.; Exindari, M.K.; Karantas, I.D.; Bikiaris, D.N. Porous dressings of modified chitosan with poly(2-hydroxyethyl acrylate) for topical wound delivery of levofloxacin. Carbohydr. Polym. 2016, 143, 90-99. [CrossRef]

91. López-Iglesias, C.; Barros, J.; Ardao, I.; Monteiro, F.j.; Alvarez-Lorenzo, C.; Gómez-Amoza, J.L.; García-González, C.A. Vancomycin-loaded chitosan aerogel particles for chronic wound applications. Carbohydr. Polym. 2019, 204, $223-231$. [CrossRef]

92. Shao, W.; Wu, J.; Wang, S.; Huang, M.; Liu, X.; Zhang, R. Construction of silver sulfadiazine loaded chitosan composite sponges as potential wound dressings. Carbohydr. Polym. 2017, 157, 1963-1970. [CrossRef]

93. Wichai, S.; Chuysinuan, P.; Chaiarwut, S.; Ekabutr, P.; Supaphol, P. Development of bacterial cellulose/ alginate/chitosan composites incorporating copper (II) sulfate as an antibacterial wound dressing. J. Drug Deliv. Sci. Technol. 2019, 51, 662-671. [CrossRef]

94. Rahimi, M.; Ahmadi, R.; Samadi Kafil, H.; Shafiei-Irannejad, V. A novel bioactive quaternized chitosan and its silver-containing nanocomposites as a potent antimicrobial wound dressing: Structural and biological properties. Mater. Sci. Eng. C 2019, 101, 360-369. [CrossRef]

95. Regiel-Futyra, A.; Liskiewicz, M.; Sebastian, V.; Irusta, S.; Arruebo, M.; Stochel, G.; Kyziol, A. Development of non cytotoxic chitosan-gold nanocomposites as efficient antibacterial materials. ACS Appl. Mater. Interfaces 2015, 7, e1099.

96. Bal-Ozturk, A.; Karal-Yilmaz, O.; Akguner, Z.P.; Aksu, S.; Tas, A.; Olmez, H. Sponge-like chitosan-based nanostructured antibacterial material as a topical hemostat. J. Appl. Polym. Sci. 2019, 136, 47522. [CrossRef]

97. Cai, N.; Li, C.; Han, C.; Luo, X.; Shen, L.; Xue, Y.; Yu, F. Tailoring mechanical and antibacterial properties of chitosan/gelatin nanofiber membranes with $\mathrm{Fe} 3 \mathrm{O} 4$ nanoparticles for potential wound dressing application. Appl. Surface Sci. 2016, 369, 492-500. [CrossRef]

98. Woo, C.H.; Choi, Y.C.; Choi, J.S.; Lee, H.Y.; Cho, Y.W. A bilayer composite composed of TiO2-incorporated electrospun chitosan membrane and human extracellular matrix sheet as a wound dressing. J. Biomater. Sci. Polym. Ed. 2015, 26, 841-854. [CrossRef]

99. Gomes Neto, R.J.; Genevro, G.M.; Paulo, L.d.A.; Lopes, P.S.; de Moraes, M.A.; Beppu, M.M. Characterization and in vitro evaluation of chitosan/konjac glucomannan bilayer film as a wound dressing. Carbohydr. Polym. 2019, 212, 59-66. [CrossRef] 
100. Güneş, S.; Tihmınlığlu, F. Hypericum perforatum incorporated chitosan films as potential bioactive wound dressing material. Int. J. Biol. Macromol. 2017, 102, 933-943. [CrossRef]

101. Silva, S.S.; Popa, E.G.; Gomes, M.E.; Cerqueira, M.; Marques, A.P.; Caridade, S.G.; Teixeira, P.; Sousa, C.; Mano, J.F.; Reis, R.L. An investigation of the potential application of chitosan/aloe-based membranes for regenerative medicine. Acta Biomater. 2013, 9, 6790-6797. [CrossRef]

102. Altiok, D.; Altiok, E.; Tihminlioglu, F. Physical, antibacterial and antioxidant properties of chitosan films incorporated with thyme oil for potential wound healing applications. J. Mat. Sci. Mater. Med. 2010, 21, 2227-2236. [CrossRef]

103. Noori, S.; Kokabi, M.; Hassan, Z.M. Poly(vinyl alcohol)/chitosan/honey/clay responsive nanocomposite hydrogel wound dressing. J. Appl. Polym. Sci. 2018, 135, 46311. [CrossRef]

104. Cheng, B.; Pei, B.; Wang, Z.; Hu, Q. Advances in chitosan-based superabsorbent hydrogels. RSC Adv. 2017, 7, 42036-42046. [CrossRef]

105. Cui, Z.; Zheng, Z.; Lin, L.; Si, J.; Wang, Q.; Peng, X.; Chen, W. Electrospinning and crosslinking of polyvinyl alcohol/chitosan composite nanofiber for transdermal drug delivery. Adv. Polym. Technol. 2018, 37, 1917-1928. [CrossRef]

106. Rogina, A.; Ivanković, M.; Ivanković, H. Preparation and characterization of nano-hydroxyapatite within chitosan matrix. Mater. Sci. Eng. C 2013, 33, 4539-4544. [CrossRef]

107. Ressler, A.; Ródenas-Rochina, J.; Ivanković, M.; Ivanković, H.; Rogina, A.; Ferrer, G.G. Injectable chitosanhydroxyapatite hydrogels promote the osteogenic differentiation of mesenchymal stem cells. Carbohydr. Polym. 2018, 197, 469-477. [CrossRef]

108. Zhou, P.; Xia, Y.; Cheng, X.; Wang, P.; Xie, Y.; Xu, S. Enhanced bone tissue regeneration by antibacterial and osteoinductive silica-HACC-zein composite scaffolds loaded with rhBMP-2. Biomaterials 2014, 35, 10033-10045. [CrossRef]

109. García-González, C.A.; Barros, J.; Rey-Rico, A.; Redondo, P.; Gómez-Amoza, J.L.; Concheiro, A.; Alvarez-Lorenzo, C.; Monteiro, F.J. Antimicrobial Properties and Osteogenicity of Vancomycin-Loaded Synthetic Scaffolds Obtained by Supercritical Foaming. ACS Appl. Mater. Interfaces 2018, 10, 3349-3360. [CrossRef]

110. Park, J.H.; Cho, Y.W.; Chung, H.; Kwon, I.C.; Jeong, S.Y. Synthesis and characterization of sugar-bearing chitosan derivatives: Aqueous solubility and biodegradability. Biomacromolecules 2003, 4, 1087-1091. [CrossRef]

111. Salar, S.; Mehrnejad, F.; Sajedi, R.H.; Arough, J.M. Chitosan nanoparticles-trypsin interactions: Bio-physicochemical and molecular dynamics simulation studies. Int. J. Biol. Macromol. 2017, 103, 902-909. [CrossRef]

112. Rassu, G.; Soddu, E.; Cossu, M.; Gavini, E.; Giunchedi, P.; Dalpiaz, A. Particulate formulations based on chitosan for nose-to-brain delivery of drugs. A review. J. Drug Deliv. Sci. Technol. 2016, 32, 77-87. [CrossRef]

113. Yu, S.; Xu, X.; Feng, J.; Liu, M.; Hu, K. Chitosan and chitosan coating nanoparticles for the treatment of brain disease. Int. J. Pharm. 2019, 560, 282-293. [CrossRef]

114. Santander-Ortega, M.J.; Plaza-Oliver, M.; Rodríguez-Robledo, V.; Castro-Vázquez, L.; Villaseca-González, N.; González-Fuentes, J.; Marcos, P.; Arroyo-Jiménez, M.M.; Lozano, M.V. Colloids for drug delivery to the brain. J. Drug Deliv. Sci. Technol. 2017, 42, 193-206. [CrossRef]

115. Kulkarni, A.D.; Patel, H.M.; Surana, S.J.; Vanjari, Y.H.; Belgamwar, V.S.; Pardeshi, C.V. N,N,N-Trimethyl chitosan: An advanced polymer with myriad of opportunities in nanomedicine. Carbohydr. Polym. 2017, 157, 875-902. [CrossRef] [PubMed]

116. Pardeshi, C.V.; Belgamwar, V.S. Controlled synthesis of N,N,N-trimethyl chitosan for modulated bioadhesion and nasal membrane permeability. Int. J. Biol. Macromol. 2016, 82, 933-944. [CrossRef]

117. Pardeshi, C.V.; Belgamwar, V.S. N,N,N-trimethyl chitosan modified flaxseed oil based mucoadhesive neuronanoemulsions for direct nose to brain drug delivery. Int. J. Biol. Macromol. 2018, 120, 2560-2571. [CrossRef]

118. Mooney, R.; Weng, Y.; Garcia, E.; Bhojane, S.; Smith-Powell, L.; Kim, S.U.; Annala, A.J.; Aboody, K.S.; Berlin, J.M. Conjugation of $\mathrm{pH}$-responsive nanoparticles to neural stem cells improves intratumoral therapy. J. Controll Release 2014, 191, 82-89. [CrossRef]

119. Turabee, M.H.; Jeong, T.H.; Ramalingam, P.; Kang, J.H.; Ko, Y.T. N,N,N-trimethyl chitosan embedded in situ Pluronic F127 hydrogel for the treatment of brain tumor. Carbohydr. Polym. 2019, 203, 302-309. [CrossRef]

120. Raj, R.; Wairkar, S.; Sridhar, V.; Gaud, R. Pramipexole dihydrochloride loaded chitosan nanoparticles for nose to brain delivery: Development, characterization and in vivo anti-Parkinson activity. Int. J. Biol. Macromol. 2018, 109, 27-35. [CrossRef] 
121. Ray, S.; Sinha, P.; Laha, B.; Maiti, S.; Bhattacharyya, U.K.; Nayak, A.K. Polysorbate 80 coated crosslinked chitosan nanoparticles of ropinirole hydrochloride for brain targeting. J. Drug Deliv. Sci. Technol. 2018, 48, 21-29. [CrossRef]

122. Kosaraju, J.; Gali, C.C.; Khatwal, R.B.; Dubala, A.; Chinni, S.; Holsinger, R.M.D.; Madhunapantula, V.S.R.; Muthureddy Nataraj, S.K.; Basavan, D. Saxagliptin: A dipeptidyl peptidase-4 inhibitor ameliorates streptozotocin induced Alzheimer's disease. Neuropharmacology 2013, 72, 291-300. [CrossRef]

123. Fernandes, J.; Ghate, M.V.; Basu Mallik, S.; Lewis, S.A. Amino acid conjugated chitosan nanoparticles for the brain targeting of a model dipeptidyl peptidase-4 inhibitor. Int. J. Pharm. 2018, 547, 563-571. [CrossRef]

124. Kaur, S.; Manhas, P.; Swami, A.; Bhandari, R.; Sharma, K.K.; Jain, R.; Kumar, R.; Pandey, S.K.; Kuhad, A.; Sharma, R.K.; et al. Bioengineered PLGA-chitosan nanoparticles for brain targeted intranasal delivery of antiepileptic TRH analogues. Chem. Eng. J. 2018, 346, 630-639. [CrossRef]

125. Fisher, R.S.; Boas, W.v.E.; Blume, W.; Elger, C.; Genton, P.; Lee, P.; Engel, J., Jr. Epileptic Seizures and Epilepsy: Definitions Proposed by the International League Against Epilepsy (ILAE) and the International Bureau for Epilepsy (IBE). Epilepsia 2005, 46, 470-472. [CrossRef] [PubMed]

126. Kaye, C.M.; Nicholls, B. Clinical Pharmacokinetics of Ropinirole. Clin. Pharmacokinet 2000, 39, $243-254$. [CrossRef]

127. Liu, S.; Yang, S.; Ho, P.C. Intranasal administration of carbamazepine-loaded carboxymethyl chitosan nanoparticles for drug delivery to the brain. Asian J. Pharm. Sci. 2018, 13, 72-81. [CrossRef]

128. Trotta, V.; Pavan, B.; Ferraro, L.; Beggiato, S.; Traini, D.; Des Reis, L.G.; Scalia, S.; Dalpiaz, A. Brain targeting of resveratrol by nasal administration of chitosan-coated lipid microparticles. Eur. J. Pharm. Biopharm. 2018, 127, 250-259. [CrossRef]

129. Jeong, Y.-I.; Jin, S.-G.; Kim, I.-Y.; Pei, J.; Wen, M.; Jung, T.-Y.; Moon, K.-S.; Jung, S. Doxorubicin-incorporated nanoparticles composed of poly(ethylene glycol)-grafted carboxymethyl chitosan and antitumor activity against glioma cells in vitro. Colloid Surf. B Biointerfaces 2010, 79, 149-155. [CrossRef]

130. Bruinsmann, F.A.; Pigana, S.; Aguirre, T.; Souto, D.G.; Pereira, G.G.; Bianchera, A.; Fasiolo, L.T.; Colombo, G.; Marques, M.; Pohlmann, A.R.; et al. Chitosan-Coated Nanoparticles: Effect of Chitosan Molecular Weight on Nasal Transmucosal Delivery. Pharmaceutics 2019, 11, 86. [CrossRef]

131. Ramreddy, S.; Janapareddi, K. Brain targeting of chitosan-based diazepam mucoadhesive microemulsions via nasal route: Formulation optimization, characterization, pharmacokinetic and pharmacodynamic evaluation. Drug Dev. Ind. Pharm. 2019, 45, 147-158. [CrossRef] [PubMed]

132. Tzeyung, A.S.; Shadab, M.L.; Bhattamisra, S.K.; Madheswaren, T.; Alhakamy, N.A.; Aldawsari, H.M.; Radhakrishnan, A.K. Fabrication, Optimization, and Evaluation of Rotigotine-Loaded Chitosan Nanoparticles for Nose-To-Brain Delivery. Pharmaceutics 2019, 11, 26. [CrossRef]

133. Rassu, G.; Porcu, E.; Fancello, S.; Obinu, A.; Senes, N.; Galleri, G.; Migheli, R.; Gavini, E.; Giunchedi, P. Intranasal Delivery of Genistein-Loaded Nanoparticles as a Potential Preventive System against Neurodegenerative Disorders. Pharmaceutics 2018, 11, 8. [CrossRef]

134. Qureshi, M.; Aqil, M.; Imam, S.S.; Ahad, A.; Sultana, Y. Formulation and Evaluation of Neuroactive Drug Loaded Chitosan Nanoparticle for Nose to Brain Delivery: In-vitro Characterization and In-vivo Behavior Study. Curr. Drug Deliv. 2019, 16, 123-135. [CrossRef] [PubMed]

135. Khan, A.; Aqil, M.; Imam, S.S.; Ahad, A.; Sultana, Y.; Ali, A.; Khan, K. Temozolomide loaded nano lipid based chitosan hydrogel for nose to brain delivery: Characterization, nasal absorption, histopathology and cell line study. Int. J. Biol. Macromol. 2018, 116, 1260-1267. [CrossRef]

136. Salade, L.; Wauthoz, N.; Vermeersch, M.; Amighi, K.; Goole, J. Chitosan-coated liposome dry-powder formulations loaded with ghrelin for nose-to-brain delivery. Eur. J. Pharm. Biopharm. 2018, 129, 257-266. [CrossRef]

137. Wei, H.; Lai, S.; Wei, J.; Yang, L.; Jiang, N.; Wang, Q.; Yu, Y. A Novel Delivery Method of Cyclovirobuxine D for Brain-Targeting: Chitosan Coated Nanoparticles Loading Cyclovirobuxine D by Intranasal Administration. J. Nanosci. Nanotechnol. 2018, 18, 5274-5282. [CrossRef]

138. Rinaldi, F.; Hanieh, P.; Chan, L.; Angeloni, L.; Passeri, D.; Rossi, M.; Wang, J.; Imbriano, A.; Carafa, M.; Marianecci, C. Chitosan Glutamate-Coated Niosomes: A Proposal for Nose-to-Brain Delivery. Pharmaceutics 2018, 10, 38. [CrossRef] 
139. Singh, S.K.; Hidau, M.K.; Gautam, S.; Gupta, K.; Singh, K.P.; Singh, S.K.; Singh, S. Glycol chitosan functionalized asenapine nanostructured lipid carriers for targeted brain delivery: Pharmacokinetic and teratogenic assessment. Int. J. Biol. Macromol. 2018, 108, 1092-1100. [CrossRef]

140. Rassu Gavini, E.; Catra, A.; Obinu, A.; Porcu, E.P.; Guinchedi, P. Hydroxypropyl- $\beta$-Cyclodextrin Formulated in Nasal Chitosan Microspheres as Candidate Therapeutic Agent in Alzheimers Disease. Curr. Drug. Deliv. 2018, 15, 746-748. [CrossRef] [PubMed]

141. Margret, A.A.; Ganesh Kumar, A.A. Therapeutic Paradigm to Appraise the Competence of Chitosan Oligosaccharide Lactate Targeting Monoamine Oxidase-A and PGlycoprotein to Contest Depression by Channeling the Blood Brain Barrier. Curr. Bioinform. 2018, 13, 273-279. [CrossRef]

142. Belgamwar, A.; Khan, S.; Yeole, P. Intranasal chitosan-g-HP $\beta C D$ nanoparticles of efavirenz for the CNS targeting. Artif. Cells Nanomed. Biotechnol. 2018, 46, 374-386. [CrossRef] [PubMed]

143. Kwon, S.; Park, J.H.; Chung, H.; Kwon, I.C.; Jeong, S.Y.; Kim, I.-S. Physicochemical characteristics of self-assembled nanoparticles based on glycol chitosan bearing 5 $\beta$-cholanic acid. Langmuir 2003, 19, 10188-10193. [CrossRef]

144. Mansur, A.A.; Mansur, H.S. Quantum dot/glycol chitosan fluorescent nanoconjugates. Nanoscale Res. Lett. 2015, 10, 172. [CrossRef] [PubMed]

145. Nishimura, S.; Kohgo, O.; Kurita, K.; Kuzuhara, H. Chemospecific manipulations of a rigid polysaccharide: Syntheses of novel chitosan derivatives with excellent solubility in common organic solvents by regioselective chemical modifications. Macromolecules 1991, 24, 4745-4748. [CrossRef]

146. Ahsan, S.M.; Thomas, M.; Reddy, K.K.; Sooraparaju, S.G.; Asthana, A.; Bhatnagar, I. Chitosan as biomaterial in drug delivery and tissue engineering. Int. J. Biol. Macromol. 2018, 110, 97-109. [CrossRef]

147. Agnihotri, S.A.; Mallikarjuna, N.N.; Aminabhavi, T.M. Recent advances on chitosan-based micro-and nanoparticles in drug delivery. J. Controll Release 2004, 100, 5-28. [CrossRef]

148. Amidi, M.; Mastrobattista, E.; Jiskoot, W.; Hennink, W.E. Chitosan-based delivery systems for protein therapeutics and antigens. Adv. Drug Deliv. Rev. 2010, 62, 59-82. [CrossRef] [PubMed]

149. Shi, B.; Zhang, H.; Shen, Z.; Bi, J.; Dai, S. Developing a chitosan supported imidazole Schiff-base for high-efficiency gene delivery. Polym. Chem. 2013, 4, 840-850. [CrossRef]

150. MacLaughlin, F.C.; Mumper, R.J.; Wang, J.; Tagliaferri, J.M.; Gill, I.; Hinchcliffe, M.; Rolland, A.P. Chitosan and depolymerized chitosan oligomers as condensing carriers for in vivo plasmid delivery. J. Controll Release 1998, 56, 259-272. [CrossRef]

151. Morris, V.B.; Sharma, C.P. Folate mediated histidine derivative of quaternised chitosan as a gene delivery vector. Int. J. Pharm. 2010, 389, 176-185. [CrossRef] [PubMed]

152. Raftery, R.; O’Brien, F.; Cryan, S.-A. Chitosan for gene delivery and orthopedic tissue engineering applications. Molecules 2013, 18, 5611-5647. [CrossRef]

153. Shim, G.; Kim, D.; Park, G.T.; Jin, H.; Suh, S.-K.; Oh, Y.-K. Therapeutic gene editing: Delivery and regulatory perspectives. Acta Pharmacol. Sin. 2017, 38, 738. [CrossRef]

154. Chen, R.; Zhang, H.; Yan, J.; Bryers, J.D. Scaffold-mediated delivery for non-viral mRNA vaccines. Gene Ther. 2018, 25, 556. [CrossRef]

155. O'Rorke, S.; Keeney, M.; Pandit, A. Non-viral polyplexes: Scaffold mediated delivery for gene therapy. Progr. Polym. Sci. 2010, 35, 441-458. [CrossRef]

156. Darder, M.; Colilla, M.; Ruiz-Hitzky, E. Chitosan-clay nanocomposites: Application as electrochemical sensors. Appl. Clay Sci. 2005, 28, 199-208. [CrossRef]

157. Shan, C.; Yang, H.; Han, D.; Zhang, Q.; Ivaska, A.; Niu, L. Graphene/AuNPs/chitosan nanocomposites film for glucose biosensing. Biosens. Bioelectr. 2010, 25, 1070-1074. [CrossRef] [PubMed]

158. Wang, F.; Yao, J.; Russel, M.; Chen, H.; Chen, K.; Zhou, Y.; Ceccanti, B.; Zaray, G.; Choi, M.M. Development and analytical application of a glucose biosensor based on glucose oxidase/O-(2-hydroxyl) propyl-3trimethylammonium chitosan chloride nanoparticle-immobilized onion inner epidermis. Biosens. Bioelectr. 2010, 25, 2238-2243. [CrossRef]

159. Shakya, A.K.; Nandakumar, K.S. An update on smart biocatalysts for industrial and biomedical applications. J. R. Soc. Interface 2018, 15, 20180062. [CrossRef]

160. Bharathiraja, S.; Bui, N.Q.; Manivasagan, P.; Moorthy, M.S.; Mondal, S.; Seo, H.; Phuoc, N.T.; Phan, T.T.V.; Kim, H.; Lee, K.D. Multimodal tumor-homing chitosan oligosaccharide-coated biocompatible palladium nanoparticles for photo-based imaging and therapy. Sci. Rep. 2018, 8, 500. [CrossRef] 
161. Karagozlu, M.Z.; Karadeniz, F.; Kim, S.-K. Anti-HIV activities of novel synthetic peptide conjugated chitosan oligomers. Int. J. Biol. Macromol. 2014, 66, 260-266. [CrossRef]

162. Ramana, L.N.; Sharma, S.; Sethuraman, S.; Ranga, U.; Krishnan, U.M. Evaluation of chitosan nanoformulations as potent anti-HIV therapeutic systems. Biochim. Biophys. Acta (BBA)-Gen. Subj. 2014, 1840, 476-484. [CrossRef] [PubMed]

163. Saravanakumar, K.; Jeevithan, E.; Chelliah, R.; Kathiresan, K.; Wen-Hui, W.; Oh, D.-H.; Wang, M.-H. Zinc-chitosan nanoparticles induced apoptosis in human acute T-lymphocyte leukemia through activation of tumor necrosis factor receptor CD95 and apoptosis-related genes. Int. J. Biol. Macromol. 2018, 119, 1144-1153. [CrossRef] [PubMed]

164. Adebisi, A.O.; Laity, P.R.; Conway, B.R. Formulation and evaluation of floating mucoadhesive alginate beads for targeting Helicobacter pylori. J. Pharm. Pharmacol. 2015, 67, 511-524. [CrossRef] [PubMed]

165. Zhao, R.; Li, J.; Wang, J.; Yin, Z.; Zhu, Y.; Liu, W. Development of Timolol-Loaded Galactosylated Chitosan Nanoparticles and Evaluation of Their Potential for Ocular Drug Delivery. AAPS PharmSciTech 2017, 18, 997-1008. [CrossRef] [PubMed]

166. Min, K.H.; Park, K.; Kim, Y.-S.; Bae, S.M.; Lee, S.; Jo, H.G.; Park, R.-W.; Kim, I.-S.; Jeong, S.Y.; Kim, K. Hydrophobically modified glycol chitosan nanoparticles-encapsulated camptothecin enhance the drug stability and tumor targeting in cancer therapy. J. Controll Release 2008, 127, 208-218. [CrossRef]

167. Liu, L.; Zhou, C.; Xia, X.; Liu, Y. Self-assembled lecithin/chitosan nanoparticles for oral insulin delivery: Preparation and functional evaluation. Int. J. Nanomed. 2016, 11, 761-769. [CrossRef] [PubMed]

168. Savin, C.-L.; Popa, M.; Delaite, C.; Costuleanu, M.; Costin, D.; Peptu, C.A. Chitosan grafted-poly(ethylene glycol) methacrylate nanoparticles as carrier for controlled release of bevacizumab. Mater. Sci. Eng. C 2019, 98, 843-860. [CrossRef]

169. Tammam, S.N.; Khalil, M.A.; Gawad, E.A.; Althani, A.; Zaghloul, H.; Azzazy, H.M. Chitosan gold nanoparticles for detection of amplified nucleic acids isolated from sputum. Carbohydr. Polym. 2017, 164, 57-63. [CrossRef]

170. Huang, W.-C.; Wang, W.; Xue, C.; Mao, X. Effective Enzyme Immobilization onto a Magnetic Chitin Nanofiber Composite. ACS Sustain. Chem. Eng. 2018, 6, 8118-8124. [CrossRef]

(C) 2019 by the authors. Licensee MDPI, Basel, Switzerland. This article is an open access article distributed under the terms and conditions of the Creative Commons Attribution (CC BY) license (http://creativecommons.org/licenses/by/4.0/). 